\title{
三次元測定機による上顎大曰歯の歯䅡線の計測
}

\author{
久保田公雄 ${ }^{*}$ 村 松 - ${ }^{* *}$ \\ ${ }^{*}$ 日本大学松戸荬学部第 1 解剖学教室（主任 : 久保田公雄助教授) \\ ${ }^{* *}$ 日本大学菌学部解剖学教室第 1 講座 (主任 : 北川 正教授)
}

〔受付: 平成 3 年 5 月 23 日〕

\section{Measurement of the cervical line of the upper molars with a three-dimensional} measuring machine

\author{
Kimio Kubota ${ }^{*}$ and Hazime Muramatsu ${ }^{* *}$ \\ *Department of Anatomy Nihon University School of Dentistry \\ at Matsudo \\ ${ }^{* *}$ Department of Anatomy Nihon University School of Dentistry \\ 2-870-1 Matsudoshi Sakaechyo Nishi, Chiba-ken (271) \\ (Chief: Associate Prof. Kimio Kubota) \\ [Accepted for publication: May 23, 1991]
}

Key words : molar/ cervical line/three-dimensional measurement

\begin{abstract}
Earlier attempts have been made to determine the form and position of the cervical line using various methods, but detailed observations have been relatively difficult and not all of them were always satisfactory.

In this study, measurements using a three-dimensional measuring machine have been successfully performed with the following results.

When the first and second molars were compared after plotting the contours of the cervical line, a shift in the mesiodistal direction was found in the case of both males and females. When the diameters between each of the points measured were calculated and compared, however, no significant differences could be detected at most of the points measured, though the first molar generally tended to be larger than second molar.

Thus the measurement points on the second molar tended to deflect more mesially than the first molar.

When males and females were compared, both the first and second molars were always larger in males than in females, and a similar tendency was found in the case of diameter. However, the differences between males and females in measurements of the second molar were smaller than in the case of the first molar.

With regard to the lateral aspect of the carvical line, no significant difference could be detected between the first and the second molar of the male, but differences could be found in the corresponding mesial and buccal sides in the case of the female. And when males and the females were compared, there were some parts where significant differences could be seen in the buccal side and some parts in mesial side of the first molar.

There were no significant differences, and similar morphology was found in both males and females of the second molar.
\end{abstract}


歯の形状あるいは形質を多角的に 観察すること によって，歯から多くの情報を引き出すことが試 みられ, その結果について解剖学, 人類学そして 臨床歯学の立場からの検討が加えられて今日に至 り，それらの枚挙にいとまがない。

歯頝線の形態についても同様の観察がなされ， 歯の解剖学に関する成書にその概略が 示されてい るが，全般的に前歯についてのものが多く，大臼 歯での歯陑線の形態は他の歯と比較して，その形 状についての詳細な説明には乏しく，今日に至る までその具体的な形態あるいは位置について明ら かにされているとは言い難い。

歯冠と歯根の境界をなす歯䅡線の正確な 形状を 把握することは, 解剖学的にも臨床学的にも必要 であることは言うまでもない。しかし，歯䅡部の くびれあるいは著しい起伏により，歯䅡線の形状 を正確に捕えることに困難が伴うことがその原因 の1つと考えられ，これらを補うための種々な方 法が多くの研究者により考案され, 歯䅡部の形態 と位置を具体的に示すことが試みられてきた。そ の代表的な方法として，一定の基準に従って描い た等高線図から歯頝線を観察する方法 ${ }^{1-3)}$, 歯頝線 上に描いた線を樹脂上に転写させてその 展開図を 求めて観察する方法，およびニクロム線等の金属 線を歯䅡線上に巻いた上で，咬合面方向からX線 撮影してその輪郭を捕える方法")，あるいは石高 模型を一定の角度で縦断してその断面形状を観察 する方法 ${ }^{5,6)}$ ，および歯䅡線より外方一膨隆した部 分を削除した上で，歯䅡線上をヒューズで囲み， これをセロテープに貼り戻して展開観察する方 法"等である。しかし，これらのいずれもが平面 的な観察であることは否めず，歯䅡線の三次元的 位置に関する計測に対して必ずしも適正であると は言い難い。このことからも，歯䅡線の詳細な観 察には困難さを伴うことを物語っていると言えよ う。このような状況下において, 近年, 測定機器 の開発あるいは既存の精密測定機器の 歯への応用 により，観察の方法も年を追って改良され，ょり 正確に結果が得られるようになってきたことに伴 い，新しい知見を求める試みがなされている。

著者らは，歯の持つ複雑な形態に対応した新し

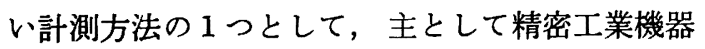

の分野での仕上り精度の測定に用いられる三次元 測定機の特性を利用し，特に，これまでの方法で は困難であると思われる部位についての形態や形 質に関する再吟味を含めて新しい情報の収集を行 っている。

今回, これらの一連の観察の一環として, 上頡 大曰歯における歯頝線を数量的に捕えることを目 的として，三次元測定機を応用した計測と観察を 行った結果，歯頚線の位置を三次元的に捕えるこ とができた。これによって, 輪郭曲線の形状およ び側面観展開図での波形の形状が 描かれたので, その詳細について報告する。

\section{材料と方法}

材料として使用した歯は，咬耗あるいは摩耗の 出来得る限り少ない上顎第 1 大臼歯男子 22 本, 女 子26本, 第 2 大臼歯男子 33 本, 女子 23 本の計104本 である。

歯頸線の 形態は不規則であるため ${ }^{81}$ ，計測に先 んじ，実体顕微鏡下で材料とした各々の歯の歯頝 線上に先細の鉛筆で線引きを行った。また，歯冠 から離れてエナメル質が小島状に存在する場 合 は, 計測の対象から除外した。次いで，歯牙を 保持するための プラスチック製容器内に, 藤田 ${ }^{91}$ の歯軸の概念に基づいて 歯根部約 $3 / 4$ 程度までを 埋め込み，この種の一連の観察に対して使用する ため，著者らが考案した特殊な固定装置 (Fig. 1) に容器を固定し, 三豊製マイクロコード超小型三 次元測定機 MXF203 を用いて, 歯䅡線上に直接 接触子を接触させることによって計測した。

計測の際の 基準は, 咬合面での 近心煩側窩 ${ }^{18)}$ （以下 $\mathrm{fmb}$ と記す）の位置を歯軸すなわち， $\mathrm{Z}$ 軸 と並行に近心煩側咬頭頂（以下 $\mathrm{Pa}$ と記す）の高 さまで移動してこれを原点とし，原点と $\mathrm{Pa}$ を結 ぶ線を X軸，原点を通りX軸と直交する線を $\mathrm{Y}$ 軸 とした(Fig. 2)。

歯頝線の計測は， $\mathrm{Pa}$ に対応する歯䅡線上の位 置から 6 度ごとに近心，舌側，遠心そして煩側の 順に合計60点の計測点について, $\mathrm{X}, \mathrm{Y}$ 座標值, $\mathrm{fmb}$ から計測点までの水平距離 (L) および $\mathrm{Pa}$ から歯䅡線までの高さ（Z）を求めた。これらの 計測平均值から，第 1 および第 2 大臼歯の歯䅡線 


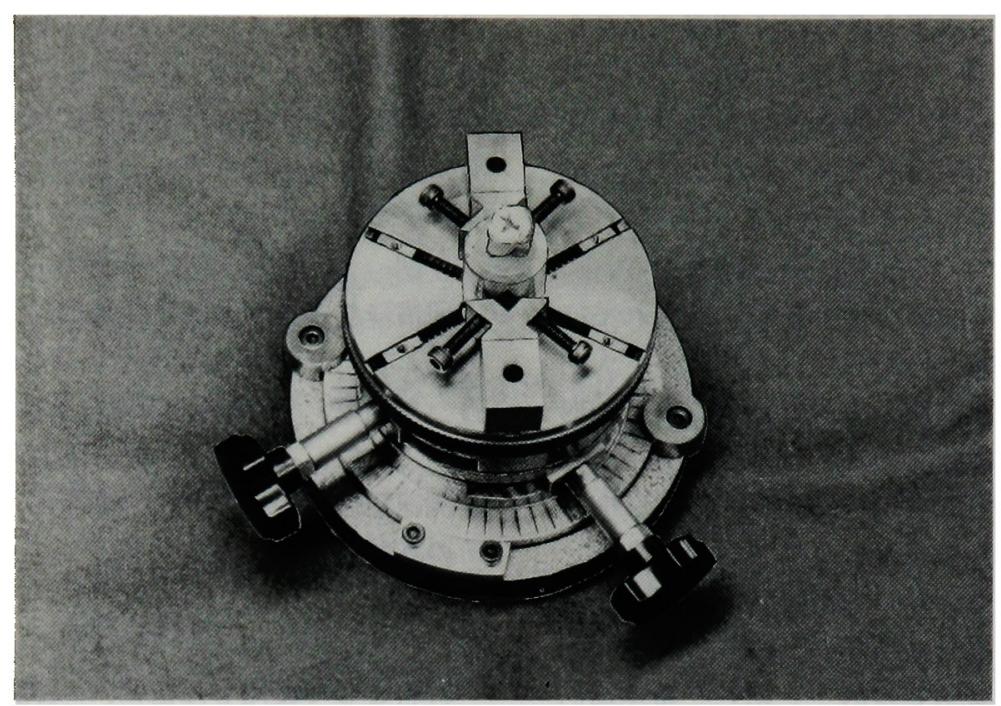

Fig. 1 The fixed apparatus of tooth
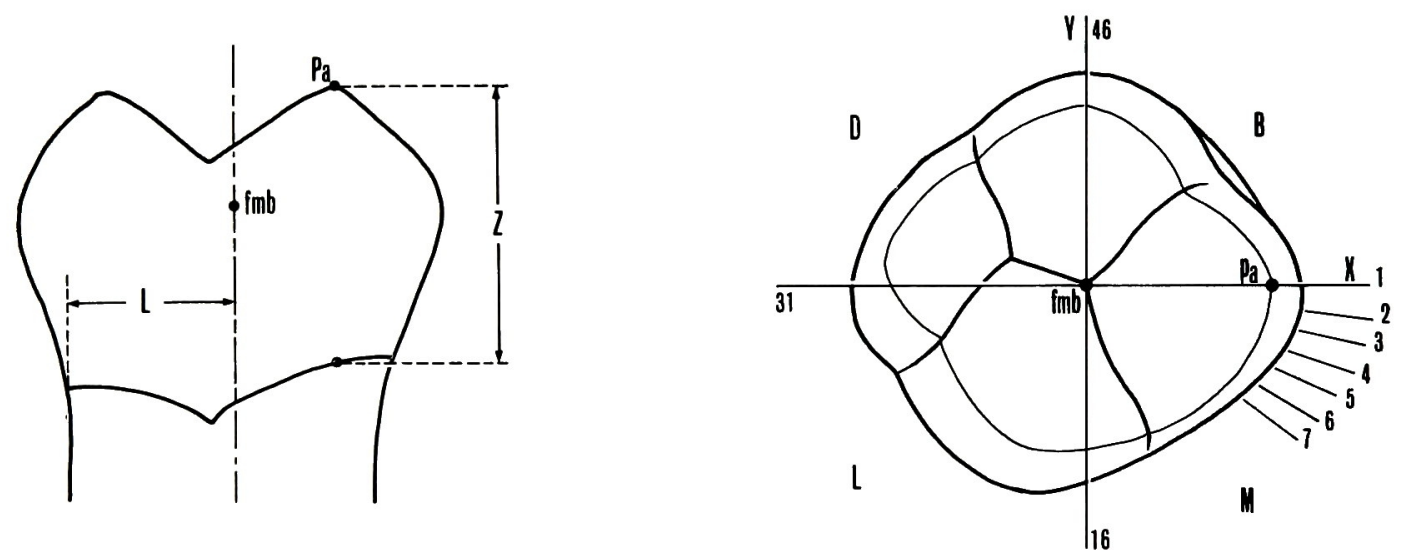

Fig. 2 Standard points and measuring portion of upper first and second molars

$\mathrm{Pa}$ : Paracone, fmb: Mesiobuccal fossa, $Z$ : Distance from the cusp tip to the cervical line

の形状を描き，第 1 と第 2 大臼歯間および男女間 の形態および位置を比較し，2つの標本平均值に おける 差の有意性について $1 \%$ \%よび $5 \%$ 水準で t 検定による検討を行った。

\section{成 績}

1) 歯頝線輪郭曲線

上顎第 1 および第 2 大臼歯の 歯頝線の座標平均 值および水平距離は, Table 1〜 4 に示した通りで あった。男女いずれの計測值ともに突飛な值を示 す部分は見当たらず，なだらかな変化を呈し，本 観察の結果が歯頝線の平均形態を正確に 表してい
るとみなされた。

これらの座標平均值に基づいた男子の第 1 大臼 歯の歯䅡線輪郭曲線を Fig. 3 に示した。計測の 基準は図から明らかなように，fmb を原点として 計測点 1 と 31 を結ぶ線が座標のX軸，そして16と 46を結ぶ線がY軸となる。

表からは歯の各々の方向を 確定することはでき ないが, Fig. 3 より計測点の46から 1 までの範囲の 第 1 象限が煩側 (B)，31から46の範囲の第 2 象限 が遠心（D)，16から31の範囲の第 3 象限が 舌側 (L) そして 1 から 16 の範囲の第 4 象限が近心 (M) に各々相当している。ただし，同図の近心相当部 
Table 1 Measurements of cervical line of the upper first molar (Male)

\begin{tabular}{|c|c|c|c|c|c|c|c|c|c|c|c|c|}
\hline & 1 & 2 & 3 & 4 & 5 & 6 & 7 & 8 & 9 & 10 & 11 & 12 \\
\hline $\mathrm{X}$ mean & 5.04 & 4.86 & 4.58 & 4.32 & 3.96 & 3.65 & 3.29 & 2.92 & 2.56 & 2.21 & 1.83 & 1.47 \\
\hline S D & 0.43 & 0.43 & 0.41 & 0,41 & 0.37 & 0.34 & 0.32 & 0.29 & 0.28 & 0.28 & 0.27 & 0.26 \\
\hline $\mathrm{Y}$ mean & 0.00 & 0.53 & 1.00 & 1.43 & 1.82 & 2.17 & 2.48 & 2.74 & 2.98 & 3.24 & 3.37 & 3.54 \\
\hline S D & - & 0.11 & 0.14 & 0.18 & 0.21 & 0.24 & 0.27 & 0.29 & 0.31 & 0.29 & 0.35 & 0.35 \\
\hline $\mathrm{L}$ mean & 5.04 & 4.89 & 4.73 & 4.52 & 4.37 & 4.24 & 4.12 & 4.02 & 3.94 & 3.89 & 3.85 & 3.84 \\
\hline S D & 0.43 & 0.43 & 0.41 & 0.43 & 0.42 & 0.40 & 0.39 & 0.38 & 0.38 & 0.39 & 0.40 & 0.38 \\
\hline $\mathrm{Z}$ mean & -7.05 & -7.02 & -7.02 & -6.88 & -6.77 & -6.64 & -6.57 & -6.52 & -6.46 & -6.44 & -6.47 & -6.51 \\
\hline \multirow[t]{2}{*}{ S D } & 0.47 & 0.49 & 0.46 & 0.48 & 0.49 & 0.45 & $\quad 0.44$ & 0.45 & 0.47 & 0.47 & 0.53 & 0.53 \\
\hline & 13 & 14 & 15 & 16 & 17 & 18 & 19 & 20 & 21 & 22 & 23 & 24 \\
\hline$X$ mean & 1.11 & 0.73 & 0.35 & 0.00 & -0.53 & -1.03 & -1.59 & -2.20 & -2.80 & -3.41 & -3.98 & -4.46 \\
\hline S D & 0.26 & 0.25 & 0.23 & 0.00 & 0.18 & 0.19 & 0.23 & 0.31 & 0.41 & 0.47 & 0.51 & 0.52 \\
\hline$Y$ mean & 3.73 & 3.92 & 4.12 & 4.34 & 4.55 & 4.72 & 4.86 & 4.96 & 4.95 & 4.76 & 4.49 & 4.07 \\
\hline S D & 0.37 & 0.43 & 0.49 & 0.56 & 0.63 & 0.66 & 0.69 & 0.73 & 0.75 & 0.72 & 0.63 & 0.52 \\
\hline $\mathrm{L}$ mean & 3.90 & 3.99 & 4.14 & 4.34 & 458 & 4.84 & 5.12 & 5.43 & 5.66 & 5.87 & 6.00 & 6.05 \\
\hline S D & 0.40 & 0.44 & 0.50 & 0.55 & 0.63 & 0.66 & 0.71 & 0.78 & 0.85 & 0.84 & 0.79 & 0.72 \\
\hline$Z$ mean & -6.49 & -6.52 & -6.55 & -6.67 & -6.80 & -6.96 & -7.05 & -7.13 & -7.24 & -7.28 & -7.27 & -7.22 \\
\hline S D & 0.50 & 0.52 & 0.57 & 0.67 & 0.67 & 0.71 & 0.70 & 0.66 & 0.62 & 0.61 & 0.62 & 0.60 \\
\hline
\end{tabular}

\begin{tabular}{|c|c|c|c|c|c|c|c|c|c|c|c|c|}
\hline & 25 & 26 & 27 & 28 & 29 & 30 & 31 & 32 & 33 & 34 & 35 & 36 \\
\hline $\mathrm{X}$ mean & -4.85 & -5.18 & -5.51 & -5.89 & -6.24 & -6.45 & -6.49 & -6.34 & -6.10 & -5.67 & -5.19 & -4.71 \\
\hline S D & 0.48 & 0.47 & 0.46 & 0.51 & 0.50 & 0.45 & 0.45 & 0.43 & 0.42 & 0.47 & 0.52 & 0.55 \\
\hline $\mathrm{Y}$ mean & 3.57 & 3.02 & 2.48 & 1.95 & 1.37 & 0.69 & 0.00 & -0.61 & -1.20 & -1.82 & -2.31 & -2.69 \\
\hline S D & 0.39 & 0.82 & 0.29 & 0.26 & 0.23 & 0.25 & - & 0.17 & 0.17 & 0.20 & 0.25 & 0.27 \\
\hline $\mathrm{L}$ mean & 6.03 & 6.00 & 6.05 & 6.21 & 6.39 & 6.49 & 6.49 & 6.37 & 6.25 & 5.96 & 5.69 & 5.45 \\
\hline S D & 0.61 & 0.55 & 0.52 & 0.55 & 0.52 & 0.45 & 0.45 & 0.43 & 0.44 & 0.50 & 0.57 & 0.63 \\
\hline$Z$ mean & -7.24 & -7.30 & -7.39 & -7.46 & -7.50 & -7.60 & -7.69 & -7.81 & -7.83 & -7.86 & -7.91 & -7.89 \\
\hline S D & 0.63 & 0.62 & 0.62 & 0.68 & 0.62 & 0.61 & 0.61 & 0.62 & 0.66 & 0.63 & 0.65 & 0.58 \\
\hline
\end{tabular}

\begin{tabular}{r|rrrrrrrrrrrr}
\hline & \multicolumn{1}{|c}{37} & \multicolumn{1}{c}{38} & \multicolumn{1}{c}{39} & \multicolumn{1}{c}{40} & \multicolumn{1}{c}{41} & 42 & 43 & \multicolumn{1}{c}{44} & \multicolumn{1}{c}{45} & 46 & 47 & 48 \\
\hline X mean & -4.21 & -3.67 & -3.15 & -2.69 & -2.24 & -1.78 & -1.34 & -0.89 & -0.45 & 0.00 & 0.55 & 1.04 \\
S D & 0.54 & 0.52 & 0.48 & 0.44 & 0.38 & 0.35 & 0.30 & 0.21 & 0.08 & - & 0.16 & 0.16 \\
Y mean & -3.09 & -3.32 & -3.60 & -3.82 & -4.03 & -4.20 & -4.38 & -4.55 & -4.63 & -4.71 & -4.71 & -4.61 \\
S D & 0.38 & 0.53 & 0.50 & 0.53 & 0.53 & 0.51 & 0.53 & 0.48 & 0.50 & 0.49 & 0.49 & 0.49 \\
L mean & 5.22 & 4.99 & 4.79 & 4.68 & 4.62 & 4.57 & 4.61 & 4.64 & 4.68 & 4.72 & 4.75 & 4.74 \\
S D & 0.64 & 0.67 & 0.68 & 0.67 & 0.63 & 0.58 & 0.54 & 0.50 & 0.50 & 0.47 & 0.48 & 0.48 \\
Z mean & -7.88 & -7.79 & -7.75 & -7.68 & -7.65 & -7.67 & -7.65 & -7.65 & -7.69 & -7.64 & -7.56 & -7.54 \\
S D & 0.59 & 0.60 & 0.56 & 0.51 & 0.49 & 0.50 & 0.48 & 0.45 & 0.40 & 0.38 & 0.38 & 0.41 \\
\hline
\end{tabular}

\begin{tabular}{r|rrrrrrrrrrrr}
\hline & \multicolumn{1}{|c}{49} & \multicolumn{1}{c}{50} & \multicolumn{1}{c}{51} & \multicolumn{1}{c}{52} & \multicolumn{1}{c}{53} & \multicolumn{1}{c}{54} & 55 & 56 & 57 & \multicolumn{1}{l}{58} & \multicolumn{1}{c}{59} & \multicolumn{1}{c}{60} \\
\hline X mean & 1.51 & 1.96 & 2.39 & 2.78 & 3.19 & 3.57 & 3.93 & 4.31 & 4.61 & 4.87 & 5.05 & 5.13 \\
S D & 0.19 & 0.24 & 0.29 & 0.33 & 0.31 & 0.34 & 0.42 & 0.47 & 0.50 & 0.50 & 0.45 & 0.44 \\
Y mean & -4.47 & -4.27 & -4.03 & -3.73 & -3.40 & -3.10 & -2.79 & -2.43 & -2.01 & -1.55 & -1.05 & -0.51 \\
S D & 0.50 & 0.49 & 0.48 & 0.46 & 0.44 & 0.41 & 0.38 & 0.36 & 0.31 & 0.25 & 0.18 & 0.13 \\
L mean & 4.73 & 4.71 & 4.69 & 4.66 & 4.64 & 4.71 & 4.83 & 4.95 & 5.04 & 5.13 & 5.18 & 5.16 \\
S D & 0.51 & 0.53 & 0.55 & .055 & 0.55 & 0.55 & 0.55 & 0.56 & 0.56 & 0.52 & 0.47 & 0.45 \\
Z mean & -7.44 & -7.41 & -7.37 & -7.49 & -7.77 & -7.62 & -7.49 & -7.35 & -7.24 & -7.12 & -6.89 & -7.02 \\
S D & 0.39 & 0.42 & 0.42 & 0.48 & 0.87 & 0.85 & 0.61 & 0.53 & 0.50 & 0.47 & 0.81 & 0.53 \\
\hline
\end{tabular}


Table 2 Measurements of cervical line of the upper second molar (Male)

\begin{tabular}{|c|c|c|c|c|c|c|c|c|c|c|c|c|}
\hline & 1 & 2 & 3 & 4 & 5 & 6 & 7 & 8 & 9 & 10 & 11 & 12 \\
\hline $\mathrm{X}$ mean & 5.39 & 5.22 & 4.97 & 4.67 & 4.35 & 3.98 & 3.59 & 3.19 & 2.79 & 2.40 & 2.01 & 1.63 \\
\hline S D & 0.66 & 0.65 & 0.60 & 0.55 & 0.48 & 0.42 & 0.37 & 0.33 & 0.28 & 0.24 & 0.21 & 0.18 \\
\hline $\mathrm{Y}$ mean & 0.00 & 0.58 & 1.08 & 1.55 & 1.97 & 2.34 & 2.65 & 2.92 & 3.16 & 3.37 & 3.56 & 3.77 \\
\hline S D & - & 0.07 & 0.15 & 0.18 & 0.22 & 0.25 & 0.27 & 0.30 & 0.32 & 0.34 & 0.38 & 0.41 \\
\hline $\mathrm{L}$ mean & 5.38 & 5.25 & 5.09 & 4.92 & 4.77 & 4.62 & 4.47 & 4.33 & 4.22 & 4.14 & 4.09 & 4.11 \\
\hline S D & 0.67 & 0.65 & 0.61 & 0.58 & 0.53 & 0.49 & 0.46 & 0.45 & 0.43 & 0.42 & 0.43 & 0.45 \\
\hline$Z$ mean & -7.11 & -7.06 & -6.95 & -6.91 & -6.81 & -6.77 & -6.75 & -6.74 & -6.75 & -6.74 & -6.76 & -6.75 \\
\hline \multirow{2}{*}{ SD } & 0.63 & 0.56 & 0.56 & 0.59 & 0.56 & 0.63 & 0.64 & 0.72 & 0.70 & 0.65 & 0.60 & 0.60 \\
\hline & 13 & 14 & 15 & 16 & 17 & 18 & 19 & 20 & 21 & 22 & 23 & 24 \\
\hline $\mathrm{X}$ mean & 1.25 & 0.85 & 0.42 & 0.00 & -0.54 & -1.09 & -1.68 & -2.31 & -2.94 & -3.56 & -4.12 & -4.59 \\
\hline SD & 0.14 & 0.09 & 0.05 & - & 0.05 & 0.11 & 0.17 & 0.22 & 0.28 & 0.33 & 0.39 & 0.46 \\
\hline $\mathrm{Y}$ mean & 3.97 & 4.20 & 4.41 & 4.61 & 4.77 & 4.93 & 5.04 & 5.08 & 5.02 & 4.83 & 4.54 & 4.07 \\
\hline S D & 0.45 & 0.46 & 0.49 & 1.47 & 0.49 & 0.54 & 0.52 & 0.51 & 0.50 & 0.45 & 0.39 & 0.41 \\
\hline $\mathrm{L}$ mean & 4.17 & 4.28 & 4.43 & 4.61 & 4.80 & 5.05 & 5.32 & 5.58 & 5.82 & 6.00 & 6.11 & 6.13 \\
\hline S D & 0.48 & 0.47 & 0.50 & 0.47 & 0.49 & 0.55 & 0.55 & 0.56 & 0.57 & 0.56 & 0.58 & 0.61 \\
\hline $\mathrm{Z}$ mean & -6.75 & -6.75 & -6.77 & -6.86 & -6.98 & -7.05 & -7.06 & -7.00 & -6.94 & -6.93 & -6.97 & -7.07 \\
\hline \multirow[t]{2}{*}{ S D } & 0.58 & 0.58 & 0.59 & 0.63 & 0.69 & 0.77 & 0.79 & 0.71 & 0.68 & 0.68 & 0.68 & 0.70 \\
\hline & 25 & 26 & 27 & 28 & 29 & 30 & 31 & 32 & 33 & 34 & 35 & 36 \\
\hline $\mathrm{X}$ mean & -4.97 & -5.30 & -5.58 & -5.83 & -6.02 & -6.09 & -6.00 & -5.76 & -5.42 & -4.93 & -4.40 & -3.91 \\
\hline S D & 0.51 & 0.50 & 0.52 & 0.55 & 0.59 & 0.64 & 0.68 & 0.73 & 0.70 & 0.70 & 0.70 & 0.62 \\
\hline $\mathrm{Y}$ mean & 3.55 & 3.00 & 2.43 & 1.84 & 1.23 & 0.59 & 0.00 & -0.64 & -1.19 & -1.64 & -2.00 & -2.30 \\
\hline S D & 0.37 & 0.29 & 0.22 & 0.18 & 0.12 & 0.06 & - & 0.08 & 0.15 & 0.23 & 0.31 & 0.36 \\
\hline $\mathrm{L}$ mean & 6.11 & 6.09 & 6.09 & 6.11 & 6.14 & 6.12 & 5.99 & 5.79 & 5.55 & 5.20 & 4.83 & 4.54 \\
\hline S D & 0.63 & 0.58 & 0.57 & 0.58 & 0.60 & 0.64 & 0.68 & 0.73 & 0.72 & 0.74 & 0.77 & 0.71 \\
\hline$Z$ mean & -7.20 & -7.31 & -7.41 & -7.47 & -7.46 & -7.42 & -7.44 & -7.48 & -7.55 & -7.61 & -7.66 & -7.70 \\
\hline S D & 0.68 & 0.69 & 0.70 & 0.74 & 0.74 & 0.72 & 0.73 & 0.71 & 0.73 & 0.77 & 0.80 & 0.76 \\
\hline
\end{tabular}

\begin{tabular}{r|rrrrrrrrrrrr}
\hline & \multicolumn{1}{|c}{37} & \multicolumn{1}{c}{38} & \multicolumn{1}{c}{39} & \multicolumn{1}{c}{40} & \multicolumn{1}{c}{41} & \multicolumn{1}{c}{42} & \multicolumn{1}{c}{43} & 44 & 45 & 46 & 47 & \multicolumn{1}{c}{48} \\
\hline X mean & -3.48 & -3.07 & -2.72 & -2.39 & -2.05 & -1.68 & -1.28 & -0.86 & -0.42 & 0.00 & 0.51 & 0.98 \\
S D & 0.53 & 0.46 & 0.39 & 0.31 & 0.23 & 0.17 & 0.12 & 0.08 & 0.04 & - & 0.05 & 0.11 \\
Y mean & -2.58 & -2.82 & -3.09 & -3.37 & -3.63 & -3.88 & -4.10 & -4.27 & -4.41 & -4.48 & -4.48 & -4.42 \\
S D & 0.39 & 0.42 & 0.44 & 0.43 & 0.41 & 0.40 & 0.39 & 0.38 & 0.39 & 0.43 & 0.48 & 0.49 \\
L mean & 4.33 & 4.17 & 4.11 & 4.14 & 4.17 & 4.23 & 4.29 & 4.36 & 4.43 & 4.48 & 4.50 & 4.53 \\
S D & 0.66 & 0.63 & 0.59 & 0.53 & 0.47 & 0.44 & 0.40 & 0.39 & 0.40 & 0.44 & 0.48 & 0.51 \\
Z mean & -7.70 & -7.69 & -7.68 & -7.69 & -7.66 & -7.68 & -7.68 & -7.69 & -7.65 & -7.62 & -7.58 & -7.53 \\
S D & 0.75 & 0.78 & 0.81 & 0.82 & 0.82 & 0.79 & 0.80 & 0.79 & 0.79 & 0.77 & 0.75 & 0.71 \\
\hline
\end{tabular}

\begin{tabular}{r|rrrrrrrrrrrr}
\hline & \multicolumn{1}{c}{49} & \multicolumn{1}{c}{50} & \multicolumn{1}{c}{51} & \multicolumn{1}{c}{52} & \multicolumn{1}{c}{53} & 54 & 55 & 56 & 57 & 58 & \multicolumn{1}{c}{59} & \multicolumn{1}{c}{60} \\
\hline X mean & 1.44 & 1.87 & 2.26 & 2.61 & 2.99 & 3.38 & 3.88 & 4.37 & 4.81 & 5.14 & 5.35 & 5.43 \\
S D & 0.82 & 0.24 & 0.31 & 0.35 & 0.39 & 0.41 & 0.44 & 0.47 & 0.53 & 0.58 & 0.62 & 0.64 \\
Y mean & -4.29 & -4.08 & -3.82 & -3.52 & -3.26 & -2.98 & -2.76 & -2.47 & -2.09 & -1.62 & -1.08 & -0.52 \\
S D & 0.54 & 0.55 & 0.54 & 0.48 & 0.43 & 0.37 & 0.32 & 0.27 & 0.23 & 0.18 & 0.12 & 0.06 \\
L mean & 4.52 & 4.49 & 4.44 & 4.38 & 4.42 & 4.51 & 4.76 & 5.03 & 5.24 & 5.39 & 5.45 & 5.46 \\
S D & 0.57 & 0.60 & 0.68 & 0.59 & 0.58 & 0.55 & 0.54 & 0.54 & 0.58 & 0.61 & 0.63 & 0.65 \\
Z mean & -7.48 & -7.49 & -7.63 & -7.81 & -7.90 & -7.87 & -7.56 & -7.36 & -7.22 & -7.19 & -7.15 & -7.12 \\
S D & 0.67 & 0.65 & 0.69 & 0.78 & 0.96 & 1.00 & 0.82 & 0.77 & 0.69 & 0.68 & 0.67 & 0.68 \\
\hline
\end{tabular}


Table 3 Measurements of cervical line of the upper first molar (Female)

\begin{tabular}{|c|c|c|c|c|c|c|c|c|c|c|c|c|}
\hline & 1 & 2 & 3 & 4 & 5 & 6 & 7 & 8 & 9 & 10 & 11 & 12 \\
\hline $\mathrm{X}$ mean & 4.88 & 4.67 & 4.40 & 4.10 & 3.82 & 3.49 & 3.18 & 2.85 & 2.51 & 2.16 & 1.82 & 1.47 \\
\hline SD & 0.46 & 0.46 & 0.40 & 0.36 & 0.32 & 0.29 & 0.25 & 0.22 & 0.20 & 0.18 & 0.15 & 0.12 \\
\hline$Y$ mean & 0.00 & 0.51 & 0.96 & 1.36 & 1.74 & 2.04 & 2.34 & 2.61 & 2.83 & 3.03 & 3.21 & 3.39 \\
\hline S D & - & 0.05 & 0.08 & 0.12 & 0.15 & 0.17 & 0.10 & 0.20 & 0.23 & 0.25 & 0.26 & 0.28 \\
\hline $\mathrm{L}$ mean & 4.88 & 4.70 & 4.51 & 4.32 & 4.19 & 4.04 & 3.95 & 3.87 & 3.79 & 3.73 & 3.69 & 3.70 \\
\hline S D & 0.46 & 0.46 & 0.41 & 0.38 & 0.35 & 0.34 & 0.31 & 0.30 & 0.30 & 0.31 & 0.31 & 0.31 \\
\hline$Z$ mean & -6.80 & -6.77 & -6.72 & -6.63 & -6.53 & -6.47 & -6.41 & -6.37 & -6.40 & -6.40 & -6.43 & -6.47 \\
\hline \multirow[t]{2}{*}{ S D } & 0.43 & 0.43 & 0.47 & 0.47 & 0.44 & 0.42 & 0.43 & 0.42 & 0.42 & 0.42 & 0.44 & 0.43 \\
\hline & 13 & 14 & 15 & 16 & 17 & 18 & 19 & 20 & 21 & 22 & 23 & 24 \\
\hline $\mathrm{X}$ mean & 1.13 & 0.77 & 0.39 & 0.00 & -0.46 & -1.03 & -1.63 & -2.25 & -2.90 & -3.50 & -4.04 & -4.47 \\
\hline S D & 0.10 & 0.07 & 0.04 & - & 0.19 & 0.01 & 0.18 & 0.23 & 0.28 & 0.31 & 0.32 & 0.33 \\
\hline $\mathrm{Y}$ mean & 3.59 & 3.76 & 4.01 & 4.29 & 4.52 & 4.76 & 4.95 & 5.00 & 4.96 & 4.77 & 4.41 & 3.98 \\
\hline S D & 0.32 & 0.37 & 0.44 & 0.43 & 0.46 & 0.51 & 0.53 & 0.50 & 0.48 & 0.42 & 0.34 & 0.29 \\
\hline $\mathrm{L}$ mean & 3.77 & 3.88 & 4.07 & 4.29 & 4.55 & 4.87 & 5.21 & 5.48 & 5.75 & 5.92 & 6.01 & 5.99 \\
\hline S D & 0.33 & 0.38 & 0.42 & 0.43 & 0.46 & 0.52 & 0.56 & 0.56 & 0.56 & 0.52 & 0.47 & 0.44 \\
\hline \multirow{3}{*}{$\begin{array}{r}Z \text { mean } \\
S D\end{array}$} & -6.46 & -6.47 & -6.55 & -6.70 & -6.86 & -6.91 & -6.96 & -7.06 & -7.11 & -7.14 & -7.14 & -7.17 \\
\hline & 0.45 & 0.46 & 0.49 & 0.57 & 0.51 & 0.45 & 0.44 & 0.53 & 0.59 & 0.59 & 0.55 & 0.55 \\
\hline & 25 & 26 & 27 & 28 & 29 & 30 & 31 & 32 & 33 & 34 & 35 & 36 \\
\hline $\mathrm{X}$ mean & -4.81 & -5.12 & -5.47 & -5.83 & -6.09 & -6.21 & -6.20 & -6.00 & -5.69 & -5.26 & -4.42 & -4.31 \\
\hline S D & 0.36 & 0.41 & 0.43 & 0.44 & 0.44 & 0.44 & 0.46 & 0.51 & 0.54 & 0.53 & 0.96 & 0.50 \\
\hline$Y$ mean & 3.46 & 2.92 & 2.40 & 1.85 & 1.26 & 0.62 & 0.00 & -0.65 & -1.23 & -1.73 & -2.17 & -2.52 \\
\hline S D & 0.25 & 0.23 & 0.19 & 0.14 & 0.09 & 0.04 & - & 0.06 & 0.12 & 0.18 & 0.23 & 0.30 \\
\hline $\mathrm{L}$ mean & 5.93 & 5.89 & 5.97 & 6.12 & 6.22 & 6.26 & 6.20 & 6.04 & 5.82 & 5.54 & 5.26 & 5.00 \\
\hline S D & 0.44 & 0.47 & 0.47 & 0.46 & 0.45 & 0.45 & 0.46 & 0.52 & 0.56 & 0.56 & 0.56 & 0.58 \\
\hline $\mathrm{Z}$ mean & -7.26 & -7.36 & -7.45 & -7.49 & -7.54 & -7.59 & -7.69 & -7.70 & -7.79 & -7.79 & -7.74 & -7.67 \\
\hline S D & 0.53 & 0.59 & 0.58 & 0.59 & 0.60 & 0.58 & 0.59 & 0.54 & 0.55 & 0.56 & $\quad 0.56$ & 0.15 \\
\hline
\end{tabular}

\begin{tabular}{r|rrrrrrrrrrrr}
\hline & \multicolumn{1}{|c}{37} & \multicolumn{1}{c}{38} & \multicolumn{1}{c}{39} & \multicolumn{1}{c}{40} & \multicolumn{1}{c}{41} & 42 & 43 & 44 & 45 & 46 & 47 & 48 \\
\hline X mean & -3.83 & -3.33 & -2.90 & -2.46 & -2.07 & -1.69 & -1.29 & -0.88 & -0.43 & 0.00 & 0.51 & 0.99 \\
S D & 0.43 & 0.39 & 0.30 & 0.23 & 0.20 & 0.15 & 0.11 & 0.07 & 0.03 & - & 0.04 & 0.08 \\
Y mean & -2.86 & -2.77 & -3.31 & -3.45 & -3.66 & -3.88 & -4.10 & -4.31 & -4.48 & -4.57 & -4.59 & -4.53 \\
S D & 0.35 & 0.33 & 0.34 & 0.33 & 0.36 & 0.36 & 0.36 & 0.35 & 0.39 & 0.35 & 0.35 & 0.35 \\
L mean & 4.76 & 4.51 & 4.37 & 4.24 & 4.21 & 4.24 & 4.30 & 4.40 & 4.48 & 4.57 & 4.62 & 4.64 \\
S D & 0.54 & 0.54 & 0.45 & 0.40 & 0.41 & 0.39 & 0.37 & 0.36 & 0.34 & 0.33 & 0.35 & 0.36 \\
Z mean & -7.64 & -7.60 & -7.54 & -7.50 & -7.50 & -7.50 & -7.47 & -7.43 & -7.42 & -7.33 & -7.25 & -7.18 \\
S D & 0.49 & 0.54 & 0.51 & 0.54 & 0.58 & 0.50 & 0.48 & 0.48 & 0.53 & 0.54 & 0.56 & 0.57 \\
\hline
\end{tabular}

\begin{tabular}{|c|c|c|c|c|c|c|c|c|c|c|c|c|}
\hline & 49 & 50 & 51 & 52 & 53 & 54 & 55 & 56 & 57 & 58 & 59 & 60 \\
\hline $\mathrm{X}$ mean & 1.46 & 1.90 & 2.31 & 2.69 & 3.10 & 3.47 & 3.89 & 4.29 & 4.60 & 4.86 & 4.99 & 5.01 \\
\hline SD & 0.12 & 0.15 & 0.17 & 0.19 & 0.20 & 0.23 & 0.26 & 0.28 & 0.31 & 0.34 & 0.39 & 0.44 \\
\hline$Y$ mean & -4.41 & -4.19 & -3.95 & -3.66 & -3.40 & -3.08 & -2.78 & -2.43 & -2.01 & -1.54 & -1.02 & -0.49 \\
\hline S D & 0.35 & 0.33 & 0.29 & 0.26 & 0.22 & 0.20 & 0.18 & 0.16 & 0.13 & 0.11 & 0.08 & 0.04 \\
\hline $\mathrm{L}$ mean & 4.65 & 4.61 & 4.58 & 4.54 & 4.60 & 4.64 & 4.79 & 4.93 & 5.02 & 5.10 & 5.13 & 5.08 \\
\hline S D & 0.37 & 0.37 & 0.34 & 0.32 & 0.30 & 0.31 & 0.32 & 0.32 & 0.34 & 0.36 & 0.42 & 0.43 \\
\hline$Z$ mean & -7.20 & -7.21 & -7.33 & -7.49 & -7.48 & -7.50 & -7.25 & -6.99 & -6.89 & -6.80 & -6.77 & -6.79 \\
\hline S D & 0.65 & 0.61 & 0.60 & 0.83 & 0.77 & 1.04 & 0.88 & 0.60 & 0.55 & 0.50 & 0.47 & 0.46 \\
\hline
\end{tabular}


Table 4 Measurerments of cervical line of the upper second molar (Female)

\begin{tabular}{|c|c|c|c|c|c|c|c|c|c|c|c|c|}
\hline & 1 & 2 & 3 & 4 & 5 & 6 & 7 & 8 & 9 & 10 & 11 & 12 \\
\hline $\mathrm{X}$ mean & 5.16 & 4.97 & 4.70 & 4.43 & 4.08 & 3.75 & 3.41 & 3.07 & 2.64 & 2.26 & 1.88 & 1.52 \\
\hline S D & 0.31 & 0.32 & 0.33 & 0.32 & 0.26 & 0.23 & 0.19 & 0.25 & 0.18 & 0.17 & 0.16 & 0.13 \\
\hline Y mean & 0.00 & 0.56 & 1.04 & 1.47 & 1.86 & 2.21 & 2.53 & 2.79 & 2.94 & 3.19 & 3.35 & 3.53 \\
\hline S D & - & 0.41 & 0.07 & 0.10 & 0.11 & 0.12 & 0.13 & 0.16 & 0.25 & 0.23 & 0.27 & 0.30 \\
\hline $\mathrm{L}$ mean & 5.16 & 5.00 & 4.82 & 4.65 & 4.49 & 4.35 & 4.25 & 4.12 & 4.00 & 3.91 & 3.80 & 3.81 \\
\hline S D & 0.31 & 0.32 & 0.34 & 0.33 & 0.29 & 0.25 & 0.24 & 0.24 & 0.26 & 0.29 & 0.33 & 0.37 \\
\hline$Z$ mean & -7.14 & -7.08 & -7.00 & -6.89 & -6.84 & -6.80 & -6.73 & -6.73 & -6.75 & -6.76 & -6.83 & -6.85 \\
\hline S D & 0.47 & 0.43 & 0.14 & 0.44 & 0.44 & 0.46 & 0.43 & 0.46 & 0.44 & 0.43 & 0.43 & 0.41 \\
\hline & 13 & 14 & 15 & 16 & 17 & 18 & 19 & 20 & 21 & 22 & 23 & 24 \\
\hline $\mathrm{X}$ mean & 1.68 & 0.79 & 0.38 & 0.00 & -0.53 & -1.05 & -1.63 & -2.24 & -2.86 & -3.12 & -3.95 & -4.39 \\
\hline S D & 0.12 & 0.09 & 0.05 & - & 0.68 & 0.13 & 0.18 & 0.23 & 0.26 & 0.41 & 0.35 & 0.41 \\
\hline $\mathrm{Y}$ mean & 3.75 & 3.98 & 4.17 & 4.41 & 4.60 & 4.74 & 4.88 & 4.93 & 4.86 & 4.63 & 4.32 & 3.89 \\
\hline S D & 0.36 & 0.41 & 0.47 & 0.57 & 0.65 & 0.65 & 0.59 & 0.54 & 0.46 & 0.42 & 0.39 & 0.37 \\
\hline $\mathrm{L}$ mean & 3.93 & 4.06 & 4.19 & 4.41 & 4.63 & 4.81 & 5.15 & 5.42 & 5.64 & 5.76 & 5.85 & 5.87 \\
\hline S D & 0.38 & 0.42 & 0.47 & 0.57 & 0.65 & 0.59 & 0.62 & 0.59 & 0.53 & 0.51 & 0.53 & 0.56 \\
\hline$Z$ mean & -6.86 & -6.90 & -6.95 & -6.98 & -7.10 & -7.19 & -7.19 & -7.17 & -7.18 & -7.18 & -7.24 & -7.26 \\
\hline S D & 0.41 & 0.45 & 0.48 & 0.47 & 0.58 & 0.50 & 0.45 & 0.51 & 0.51 & 0.50 & 0.49 & 0.50 \\
\hline
\end{tabular}

\begin{tabular}{|c|c|c|c|c|c|c|c|c|c|c|c|c|}
\hline & 25 & 26 & 27 & 28 & 29 & 30 & 31 & 32 & 33 & 34 & 35 & 36 \\
\hline $\mathrm{X}$ mean & -4.75 & -5.05 & -5.28 & -5.56 & -5.71 & -5.80 & -5.76 & -5.56 & -5.21 & -4.75 & -4.28 & -3.75 \\
\hline S D & 0.46 & 0.50 & 0.52 & 0.52 & 0.67 & 0.79 & 0.88 & 1.00 & 1.01 & 0.97 & 0.83 & 0.64 \\
\hline $\mathrm{Y}$ mean & 3.44 & 2.85 & 2.30 & 1.74 & 1.16 & 0.56 & 0.00 & -0.62 & -1.14 & -1.58 & -1.94 & -2.21 \\
\hline S D & 0.32 & 0.27 & 0.23 & 0.19 & 0.14 & 0.08 & - & 0.10 & 0.21 & 0.31 & 0.37 & $0.3 ?$ \\
\hline $\mathrm{L}$ mean & 5.85 & 5.79 & 5.76 & 5.78 & 5.82 & 5.82 & 5.76 & 5.56 & 5.34 & 5.01 & 4.70 & 4.36 \\
\hline S D & 0.58 & 0.58 & 0.57 & 0.61 & 0.69 & 0.80 & 0.88 & 0.97 & 1.03 & 1.02 & 0.91 & 0.75 \\
\hline$Z$ mean & -7.31 & -7.42 & -7.48 & -7.41 & -7.40 & -7.43 & -7.44 & -7.51 & -7.59 & -7.75 & -7.71 & -7.73 \\
\hline S D & 0.54 & 0.55 & 0.60 & 0.60 & 0.56 & 0.56 & 0.55 & 0.55 & 0.54 & 0.56 & 0.51 & 0.45 \\
\hline
\end{tabular}

\begin{tabular}{r|rrrrrrrrrrrr}
\hline & \multicolumn{1}{|c}{37} & \multicolumn{1}{c}{38} & \multicolumn{1}{c}{39} & \multicolumn{1}{c}{40} & \multicolumn{1}{c}{41} & \multicolumn{1}{c}{42} & 43 & \multicolumn{1}{c}{44} & \multicolumn{1}{c}{45} & 46 & 47 & \multicolumn{1}{l}{48} \\
\hline X mean & -3.34 & -2.98 & -2.67 & -2.36 & -2.02 & -1.67 & -1.28 & -0.86 & -0.42 & 0.00 & 0.51 & 0.98 \\
S D & 0.50 & 0.41 & 0.33 & 0.27 & 0.22 & 0.17 & 0.11 & 0.07 & 0.04 & - & 0.04 & 0.08 \\
Y mean & -2.47 & -2.74 & -3.03 & -3.32 & -3.59 & -3.84 & -4.09 & -4.30 & -4.44 & -4.50 & -4.54 & -4.47 \\
S D & 0.36 & 0.37 & 0.36 & 0.38 & 0.37 & 0.39 & 0.35 & 0.35 & 0.35 & 0.35 & 0.34 & 0.35 \\
L mean & 4.16 & 4.05 & 4.05 & 4.07 & 4.13 & 4.21 & 4.29 & 4.39 & 4.69 & 4.51 & 4.57 & 4.58 \\
S D & 0.62 & 0.55 & 0.48 & 0.47 & 0.43 & 0.41 & 0.37 & 0.36 & 0.35 & 0.35 & 0.35 & 0.36 \\
Z mean & -7.71 & -7.90 & -7.70 & -7.72 & -7.76 & -7.75 & -7.73 & -7.79 & -7.66 & -7.65 & -7.60 & -7.60 \\
S D & 0.42 & 0.40 & 0.43 & 0.40 & 0.40 & 0.39 & 0.40 & 0.39 & 0.42 & 0.42 & 0.44 & 0.46 \\
\hline
\end{tabular}

\begin{tabular}{r|rrrrrrrrrrrr}
\hline & \multicolumn{1}{|c}{49} & 50 & \multicolumn{1}{c}{51} & \multicolumn{1}{c}{52} & \multicolumn{1}{c}{53} & 54 & 55 & 56 & 57 & 58 & 59 & 60 \\
\hline X mean & 1.44 & 1.88 & 2.27 & 2.62 & 3.02 & 3.46 & 3.94 & 4.30 & 4.75 & 5.03 & 5.21 & 5.23 \\
S D & 0.11 & 0.15 & 0.19 & 0.26 & 0.30 & 0.35 & 0.36 & 0.35 & 0.32 & 0.30 & 0.29 & 0.28 \\
Y mean & -4.33 & -4.13 & -3.86 & -3.25 & -3.28 & -3.06 & -2.81 & -2.47 & -2.07 & -1.58 & -1.06 & -0.49 \\
S D & 0.33 & 0.33 & 0.31 & 0.37 & 0.34 & 0.31 & 0.26 & 0.20 & 0.14 & 0.09 & 0.05 & 0.28 \\
L mean & 4.57 & 4.53 & 4.48 & 4.41 & 4.46 & 4.63 & 4.85 & 5.03 & 5.18 & 5.27 & 5.31 & 5.26 \\
S D & 0.35 & 0.36 & 0.37 & 0.44 & 0.46 & 0.47 & 0.44 & 0.40 & 0.35 & 0.31 & 0.30 & 0.28 \\
Z mean & -7.56 & -7.58 & -7.74 & -8.01 & -8.21 & -8.00 & -7.72 & -7.51 & -7.36 & -7.28 & -7.22 & -7.19 \\
S D & 0.47 & 0.49 & 0.59 & 0.68 & 0.81 & 0.72 & 0.57 & 0.51 & 0.48 & 0.44 & 0.47 & 0.49 \\
\hline
\end{tabular}




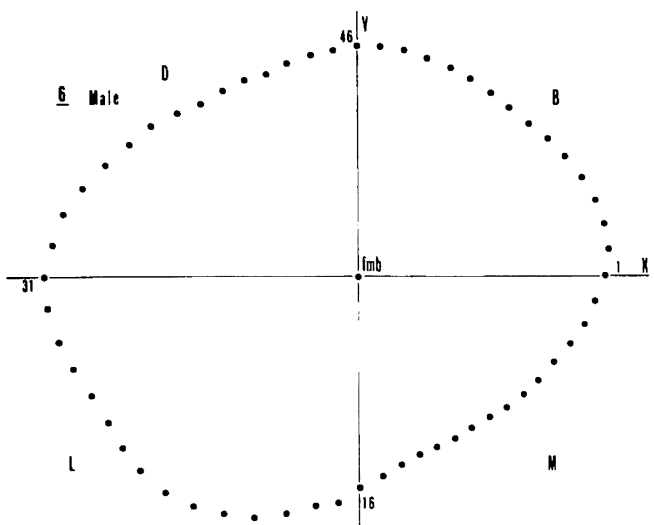

Fig. 3 Curvilinear contours of the cervical line

は，第 4 象限から第 3 象限の一部の範囲に及んで いることが予測された。

第 1 大田歯と第 2 大臼歯各々の輪郭曲線の 比較
を行うため，各計測值をプロットして描かれた男 子の結果を Fig. 4, 女子の結果を Fig. 5 に各々 示した。

Table 1〜4 に基づいて描かれた第 1 大臼歯と 第 2 大臼歯の歯頝線輪郭曲線は，男女により多 少の相違点が見られるが，男女とも第 1 大臼歯と 第 2 大鼠歯の同一計測点で近遠心方向への 差が見 られ，第 2 大臼歯の 歯頝線輪郭曲線 は 第 1 大臼 歯より全般的に近心側に偏位していることが知れ た。

$\mathrm{fmb}$ から各計測点までの水平距離の第 1 大臼歯 と第 2 大臼歯との差を Table 5 に示した。

Table 5 および Fig. 4，5 から明らかなよう に, $\mathrm{fmb}$ から各計測点までの水平距離の第 1 と第 2 大臼歯間を比較すると，第 2 象限の遠心相当部 が第 4 象限の近心相当部より差が大きく，男子で

Table 5 Difference between the first and the second molars

\begin{tabular}{l|ccccccccccccccc}
\hline & 1 & 2 & 3 & 4 & 5 & 6 & 7 & 8 & 9 & 10 & 11 & 12 & 13 & 14 & 15 \\
\hline L Male & 0.34 & 0.36 & 0.36 & 0.40 & 0.40 & 0.38 & 0.35 & 0.31 & 0.28 & 0.25 & 0.24 & 0.27 & 0.27 & 0.29 & 0.29 \\
$\quad$ Female & 0.28 & 0.30 & 0.31 & 0.33 & 0.30 & 0.31 & 0.30 & 0.25 & 0.21 & 0.18 & 0.11 & 0.11 & 0.16 & 0.18 & 0.12 \\
Z Male & 0.06 & 0.04 & 0.07 & 0.03 & 0.04 & 0.13 & 0.18 & 0.22 & 0.29 & 0.30 & 0.29 & 0.24 & 0.26 & 0.23 & 0.22 \\
Female & 0.34 & 0.31 & 0.28 & 0.26 & 0.31 & 0.33 & 0.32 & 0.36 & 0.35 & 0.36 & 0.40 & 0.38 & 0.40 & 0.43 & 0.40 \\
\hline
\end{tabular}

\begin{tabular}{l|ccccccccccccccc}
\hline & 16 & 17 & 18 & 19 & 20 & 21 & 22 & 23 & 24 & 25 & 26 & 27 & 28 & 29 & 30 \\
\hline L Male & 0.27 & 0.22 & 0.21 & 0.20 & 0.15 & 0.16 & 0.13 & 0.11 & 0.08 & 0.08 & 0.09 & 0.04 & 0.10 & 0.25 & 0.37 \\
$\quad$ Female & 0.12 & 0.08 & 0.06 & 0.06 & 0.06 & 0.11 & 0.15 & 0.16 & 0.12 & 0.08 & 0.10 & 0.21 & 0.34 & 0.40 & 0.44 \\
Z Male & 0.19 & 0.18 & 0.09 & 0.01 & 0.13 & 0.30 & 0.35 & 0.30 & 0.15 & 0.04 & 0.01 & 0.02 & 0.01 & 0.04 & 0.18 \\
$\quad$ Female & 0.28 & 0.24 & 0.28 & 0.23 & 0.11 & 0.07 & 0.04 & 0.10 & 0.09 & 0.05 & 0.06 & 0.03 & 0.08 & 0.14 & 0.16 \\
\hline
\end{tabular}

\begin{tabular}{|c|c|c|c|c|c|c|c|c|c|c|c|c|c|c|c|}
\hline & 31 & 32 & 33 & 34 & 35 & 36 & 37 & 38 & 39 & 40 & 41 & 42 & 43 & 44 & 45 \\
\hline L Male & 0.50 & 0.58 & 0.70 & 0.76 & 0.86 & 0.91 & 0.89 & 0.82 & 0.68 & 0.54 & 0.45 & 0.34 & 0.32 & 0.28 & 0.25 \\
\hline Female & 0.44 & 0.48 & 0.48 & 0.53 & 0.56 & 0.64 & 0.60 & 0.46 & 0.32 & 0.17 & 0.08 & 0.03 & 0.01 & 0.01 & 0.21 \\
\hline Z Male & 0.25 & 0.33 & 0.28 & 0.25 & 0.25 & 0.19 & 0.18 & 0.10 & 0.07 & 0.01 & 0.01 & 0.01 & 0.03 & 0.04 & 0.04 \\
\hline Female & 0.25 & 0.19 & 0.20 & 0.04 & 0.03 & 0.06 & 0.07 & 0.30 & 0.16 & 0.22 & 0.26 & 0.25 & 0.26 & 0.36 & 0.24 \\
\hline
\end{tabular}

\begin{tabular}{|c|c|c|c|c|c|c|c|c|c|c|c|c|c|c|c|}
\hline & 46 & 47 & 48 & 49 & 50 & 51 & 52 & 53 & 54 & 55 & 56 & 57 & 58 & 59 & 60 \\
\hline L Male & 0.24 & 0.25 & 0.21 & 0.21 & 0.22 & 0.25 & 0.28 & 0.22 & 0.20 & 0.07 & 0.08 & 0.20 & 0.26 & 0.27 & 0.30 \\
\hline Female & 0.06 & 0.05 & 0.06 & 0.08 & 0.08 & 0.10 & 0.13 & 0.14 & 0.01 & 0.06 & 0.10 & 0.16 & 0.17 & 0.18 & 0.18 \\
\hline Z Male & 0.02 & 0.02 & 0.01 & 0.04 & 0.08 & 0.26 & 0.32 & 0.13 & 0.25 & 0.07 & 0.01 & 0.02 & 0.07 & 0.26 & 0.10 \\
\hline Female & 0.32 & 0.35 & 0.42 & 0.36 & 0.37 & 0.41 & 0.52 & 0.73 & 0.50 & 0.47 & 0.52 & 0.47 & 0.48 & 0.45 & 0.40 \\
\hline
\end{tabular}

L : Horizontal distance from the mesiobuccal fossa to the cervical line

$Z$ : Distance from the mesiobuccal cusp tip to the cervical line 


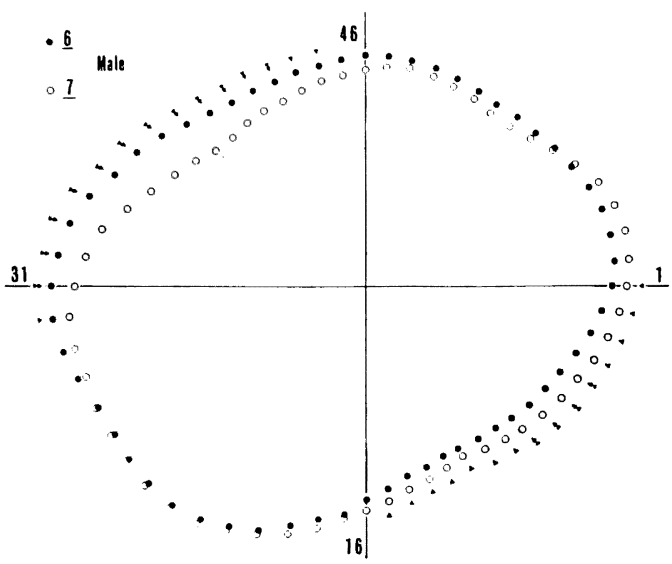

Fig. 4 Curvilinear contours of the first and the second molars in male

$\checkmark: \mathrm{P}<0.05, \rightarrow: \mathrm{P}<0.01$

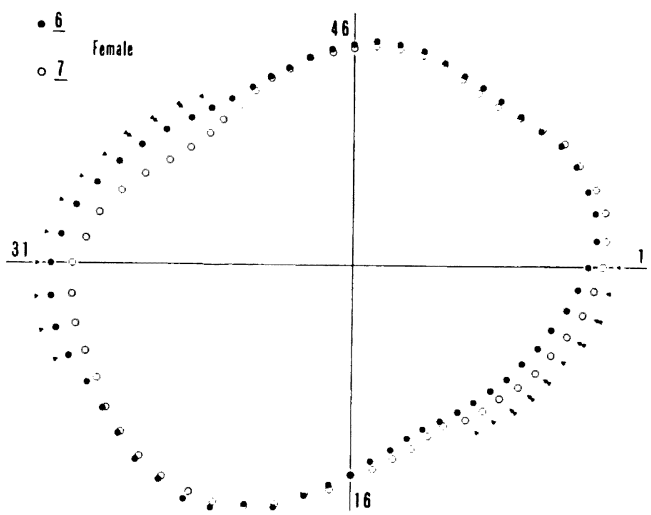

Fig. 5 Curvilinear contours of the first and the second molars in female

$\rightarrow: \mathrm{P}<0.05, \rightarrow: \mathrm{P}<0.01$

は1から15および30から44の各計測点でまた，女 子では 1 から10および28から39の各計測点で有意 差が認められた。女子の第 1 と第 2 大臼歯間での 有意差の認められる部位は，男子と比較して少な かった。これらの有意差を示寸計測点の位置は, 男子では近遠心方向への偏位として見られるのに 対し，女子では僅かながらX軸方向への偏位も見 られる傾向にあった。この結果，男女ともに第 2 大臼歯の遠心舌側隅角の突出度の減少と, 近心煩 側隅角の僅かな 突出度の 増大が 認められた。一 方, 第 1 および第 3 象限の煩側および舌側相当部 では，男女いずれも近遠心方向の偏位と比較して，
第 1 と第 2 大曰歯間での計測点の位置にほとんど 相違が認められないことが特徽的であった。

2）歯䅡線輪郭曲線の性差

各計測点の男女の水平距離（Table 1 4）に基 ゔいて, 男女間の水平距離の性差の程度を Table 6 に示した。また, 歯䅡線輪郭曲線の男女間の比 較は，第 1 大臼歯は Fig. 6 に，第 2 大臼歯は Fig. 7 に各々示した。表および図から明らか なように，第1と第 2 大臼歯のいずれも，各計 測点での水平距離は概して男子が女子より長かっ た。したがって，各計測点を結んで得られた歯䅡 線輪郭曲線は，第 1 ，第 2 大臼歯ともに男子が 女子より大きい傾向を示していた。また，第 1 大 臼歯での 男女間には，第 2 象限の遠心相当部の 31 から 43 までの各計測点で有意差が認められた (Fig. 6)。これに対して第 2 大臼歯では, 第 2 象限 の遠心相当部での男女間にほとんど差がなく，第 1 大臼歯とは逆に第 4 象限の 近心相当部の 5 から 12 範囲の計測点および第 3 象限の $27 ， 28$ 計測 点に有意な性差が認められた（Fig. 7)。この結果 から，性差の大勢は第 1 ，第 2 大臼歯ともに近遠 心方向での差が顕著であったが，第 2 大臼歯では 舌側方向への差も僅かながら存在する 傾向がみら れ，同時に第 1 と第 2 大臼歯で性差の認められる 計測点の位置が異なっていた。また，第 2 大臼歯 では煩舌方向にも有意差の存在する 部位が 2 点認 められ，全体的に男女間の差が第 1 大臼歯より大 きい傾向を示していた。しかし，第1大臼菌同様， 近遠心方向に対して煩舌方向での 男女間の差は小 さかった。

3）計測点間距離の直径による比較

歯䅡線輪郭曲線の大きさを第 1 ，第 2 大臼歯間 および男女間で具体的に比較するため，各々の計 測点での $\mathrm{fmb}$ を通る相対する 2 点間の距離を加 算すなわち，直径を算出して Table 7 に示した。 また，直径值に基づいた男子の第 1 と第 2 大臼歯 の歯䅡線輪郭曲線を Fig. 8 に，女子を Fig. 9 に 各々示した。

Table 1〜4，7 および Fig. 8，9 から明らかな ように，第 1 と第 2 大臼歯の直径での歯䅡線輪郭 曲線は，男女いずれも一部の計測点で第 2 大田歯 が第 1 大臼歯の外側にあり，位置的に逆の傾向を 
Table 6 Difference between male and famale

\begin{tabular}{cc|ccccccccccccccc}
\hline & & 1 & 2 & 3 & 4 & 5 & 6 & 7 & 8 & 9 & 10 & 11 & 12 & 13 & 14 & 15 \\
\hline $\mathrm{L}$ & 6 & 0.16 & 0.19 & 0.22 & 0.20 & 0.18 & 0.20 & 0.17 & 0.15 & 0.15 & 0.16 & 0.16 & 0.14 & 0.13 & 0.11 & 0.07 \\
& 7 & 0.22 & 0.25 & 0.27 & 0.27 & 0.28 & 0.27 & 0.22 & 0.21 & 0.22 & 0.23 & 0.29 & 0.30 & 0.24 & 0.22 & 0.24 \\
$\mathrm{Z}$ & 6 & 0.25 & 0.25 & 0.30 & 0.25 & 0.24 & 0.17 & 0.16 & 0.15 & 0.06 & 0.04 & 0.04 & 0.04 & 0.03 & 0.05 & 0.00 \\
& 7 & 0.03 & 0.02 & 0.05 & 0.02 & 0.03 & 0.03 & 0.02 & 0.01 & 0.00 & 0.02 & 0.07 & 0.10 & 0.11 & 0.15 & 0.18 \\
\hline
\end{tabular}

\begin{tabular}{cc|ccccccccccccccc}
\hline & & 16 & 17 & 18 & 19 & 20 & 21 & 22 & 23 & 24 & 25 & 26 & 27 & 28 & 29 & 30 \\
\hline $\mathrm{L}$ & 6 & 0.05 & 0.03 & 0.03 & 0.09 & 0.05 & 0.09 & 0.05 & 0.01 & 0.06 & 0.10 & 0.11 & 0.08 & 0.09 & 0.17 & 0.23 \\
& 7 & 0.20 & 0.17 & 0.24 & 0.17 & 0.16 & 0.18 & 0.24 & 0.26 & 0.26 & 0.26 & 0.30 & 0.33 & 0.33 & 0.32 & 0.30 \\
$\mathrm{Z}$ & 6 & 0.10 & 0.06 & 0.05 & 0.09 & 0.07 & 0.13 & 0.14 & 0.13 & 0.05 & 0.02 & 0.06 & 0.06 & 0.03 & 0.04 & 0.01 \\
& 7 & 0.12 & 0.12 & 0.14 & 0.13 & 0.17 & 0.24 & 0.25 & 0.27 & 0.19 & 0.11 & 0.11 & 0.07 & 0.06 & 0.06 & 0.01 \\
\hline
\end{tabular}

\begin{tabular}{|c|c|c|c|c|c|c|c|c|c|c|c|c|c|c|c|c|}
\hline & & 31 & 32 & 33 & 34 & 35 & 36 & 37 & 38 & 39 & 40 & 41 & 42 & 43 & 44 & 45 \\
\hline \multirow[t]{2}{*}{ L } & 6 & 0.29 & 0.33 & 0.43 & 0.42 & 0.43 & 0.45 & 0.46 & 0.48 & 0.42 & 0.44 & 0.41 & 0.33 & 0.31 & 0.24 & 0.20 \\
\hline & 7 & 0.23 & 0.23 & 0.21 & 0.19 & 0.13 & 0.18 & 0.17 & 0.12 & 0.06 & 0.07 & 0.04 & 0.02 & 0.00 & 0.03 & 0.26 \\
\hline \multirow[t]{2}{*}{$Z$} & 6 & 0.00 & 0.11 & 0.04 & 0.07 & 0.17 & 0.22 & 0.24 & 0.19 & 0.21 & 0.18 & 0.15 & 0.17 & 0.18 & 0.22 & 0.27 \\
\hline & 7 & 0.00 & 0.03 & 0.04 & 0.14 & 0.05 & 0.03 & 0.01 & 0.21 & 0.02 & 0.03 & 0.10 & 0.07 & 0.05 & 0.10 & 0.01 \\
\hline
\end{tabular}

\begin{tabular}{|c|c|c|c|c|c|c|c|c|c|c|c|c|c|c|c|c|}
\hline & & 46 & 47 & 48 & 49 & 50 & 51 & 52 & 53 & 54 & 55 & 56 & 57 & 58 & 59 & 60 \\
\hline \multirow[t]{2}{*}{ L } & 6 & 0.15 & 0.13 & 0.10 & 0.08 & 0.10 & 0.11 & 0.12 & 0.04 & 0.07 & 0.04 & 0.02 & 0.02 & 0.03 & 0.05 & 0.08 \\
\hline & 7 & 0.03 & 0.07 & 0.05 & 0.05 & 0.04 & 0.04 & 0.03 & 0.04 & 0.12 & 0.09 & 0.00 & 0.06 & 0.12 & 0.14 & 0.20 \\
\hline \multirow[t]{2}{*}{$\mathrm{Z}$} & 6 & 0.31 & 0.31 & 0.36 & 0.24 & 0.20 & 0.04 & 0.00 & 0.29 & 0.12 & 0.24 & 0.36 & 0.35 & 0.32 & 0.12 & 0.23 \\
\hline & 7 & 0.03 & 0.02 & 0.07 & 0.08 & 0.09 & 0.11 & 0.20 & 0.31 & 0.13 & 0.16 & 0.15 & 0.14 & 0.09 & 0.07 & 0.07 \\
\hline
\end{tabular}

L : Horizontal distance from the mesiobuccal fossa to the cervical line

$\mathrm{Z}$ : Distance from the mesiobuccal cusp tip to the cervical line

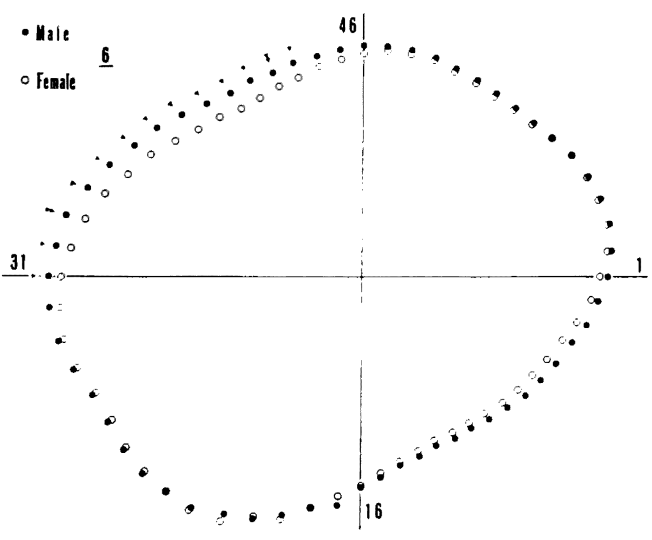

Fig. 6 Curvilinear contours of male and female in the first molars

$\rightarrow: \mathrm{P}<0.05, \longrightarrow: \mathrm{P}<0.01$

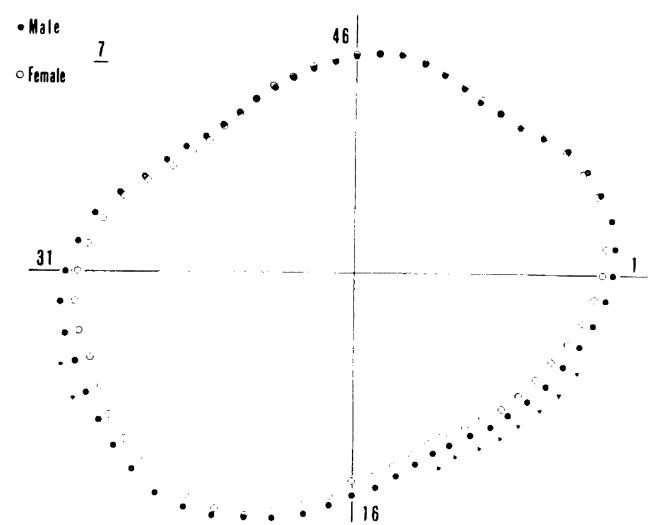

Fig. 7 Curvilinear contours of male and female in the second molars

$\rightarrow: \mathrm{P}<0.05, \longrightarrow: \mathrm{P}<0.01$ 
Table 7 Diameter of the curvilinear contours of the cervical line

\begin{tabular}{|c|c|c|c|c|c|c|c|c|c|c|c|c|c|c|c|}
\hline & 1 & 2 & 3 & 4 & 5 & 6 & 7 & 8 & 9 & 10 & 11 & 12 & 13 & 14 & 15 \\
\hline \multicolumn{16}{|l|}{ Male 6} \\
\hline $\mathrm{n}=22$ mean & 11.53 & 11.27 & 10.98 & 10.48 & 10.06 & 9.69 & 9.35 & 9.01 & 8.73 & 8.58 & 8.47 & 8.42 & 8.51 & 8.63 & 8.83 \\
\hline S D & 0.62 & 0.60 & 0.69 & 0.64 & 0.71 & 0.75 & 0.77 & 0.78 & 0.77 & 0.77 & 0.69 & 0.68 & 0.61 & 0.71 & 0.71 \\
\hline \multicolumn{16}{|l|}{ Male 7} \\
\hline $\mathrm{n}=33$ mean & 11.37 & 11.04 & 10.64 & 10.12 & 9.61 & 9.16 & 8.80 & 8.50 & 8.34 & 8.28 & 8.27 & 8.34 & 8.47 & 8.65 & 8.87 \\
\hline S D & 0.95 & 1.01 & 0.96 & 0.93 & 0.99 & 0.92 & 0.82 & 0.76 & 0.68 & 0.62 & 0.63 & 0.61 & 0.59 & 0.56 & 0.57 \\
\hline \multicolumn{16}{|l|}{ Female 6} \\
\hline $\mathrm{n}=26$ mean & 11.08 & 10.74 & 10.33 & 9.86 & 9.46 & 9.04 & 8.71 & 8.38 & 8.16 & 7.97 & 7.90 & 7.94 & 8.08 & 8.29 & 8.55 \\
\hline S D & 0.55 & 0.59 & 0.60 & 0.69 & 0.56 & 0.57 & 0.53 & 0.52 & 0.44 & 0.39 & 0.40 & 0.38 & 0.34 & 0.35 & 0.37 \\
\hline \multicolumn{16}{|l|}{ Female 7} \\
\hline $\mathrm{n}=23$ mean & 10.92 & 10.56 & 10.16 & 9.67 & 9.19 & 8.71 & 8.41 & 8.17 & 8.05 & 7.98 & 7.94 & 8.02 & 8.22 & 8.45 & 8.88 \\
\hline S D & 0.98 & 0.01 & 0.76 & 0.72 & 0.59 & 0.59 & 0.45 & 0.47 & 0.54 & 0.52 & 0.49 & 0.43 & 0.39 & 0.30 & 0.29 \\
\hline
\end{tabular}

\begin{tabular}{|c|c|c|c|c|c|c|c|c|c|c|c|c|c|c|c|}
\hline & 16 & 17 & 18 & 19 & 20 & 21 & 22 & 23 & 24 & 25 & 26 & 27 & 28 & 29 & 30 \\
\hline \multicolumn{16}{|l|}{ Male 6} \\
\hline $\mathrm{n}=22$ mean & 9.06 & 9.33 & 9.59 & 9.86 & 10.14 & 10.35 & 10.53 & 10.65 & 10.76 & 10.86 & 10.96 & 11.09 & 11.35 & 11.58 & 11.66 \\
\hline S D & 0.67 & 0.78 & 0.80 & 0.90 & 0.93 & 0.99 & 1.02 & 0.98 & 0.98 & 0.87 & 0.93 & 0.93 & 0.91 & 0.79 & 0.68 \\
\hline \multicolumn{16}{|l|}{ Male 7} \\
\hline $\mathrm{n}=33$ mean & 9.09 & 9.31 & 9.58 & 9.84 & 10.08 & 10.26 & 10.39 & 10.54 & 10.64 & 10.87 & 11.12 & 11.33 & 11.51 & 11.60 & 11.58 \\
\hline S D & 0.56 & 0.57 & 0.62 & 0.65 & 0.71 & 0.73 & 0.74 & 0.73 & 0.88 & 0.78 & 0.77 & 0.78 & 0.79 & 0.82 & 0.88 \\
\hline \multicolumn{16}{|l|}{ Female 6} \\
\hline $\mathrm{n}=26$ mean & 8.86 & 9.17 & 9.51 & 9.86 & 10.10 & 10.34 & 10.46 & 10.62 & 10.63 & 10.72 & 10.83 & 10.99 & 11.22 & 11.36 & 11.34 \\
\hline SD & 0.39 & 0.45 & 0.55 & 0.57 & 0.54 & 0.54 & 0.49 & 0.56 & 0.46 & 0.48 & 0.46 & 0.44 & 0.41 & 0.45 & 0.48 \\
\hline \multicolumn{16}{|l|}{ Female 7} \\
\hline $\mathrm{n}=23$ mean & 8.92 & 9.20 & 9.40 & 9.73 & 9.95 & 10.12 & 10.17 & 10.31 & 10.50 & 10.70 & 10.82 & 10.94 & 11.05 & 11.13 & 11.08 \\
\hline S D & 0.32 & 0.47 & 0.42 & 0.28 & 0.48 & 0.43 & 0.36 & 0.61 & 0.67 & 0.53 & 0.48 & 0.28 & 0.48 & 0.57 & 0.67 \\
\hline
\end{tabular}

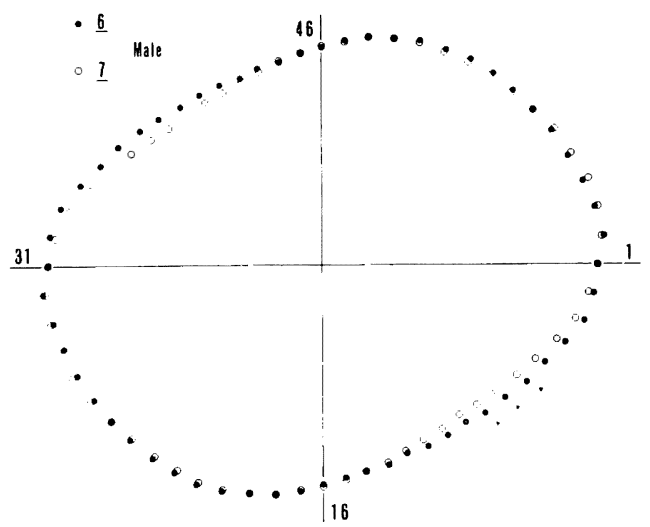

Fig. 8 Curvilinear contours of the first and the second molars in male (Diameter) $\checkmark: \mathrm{P}<0.05$

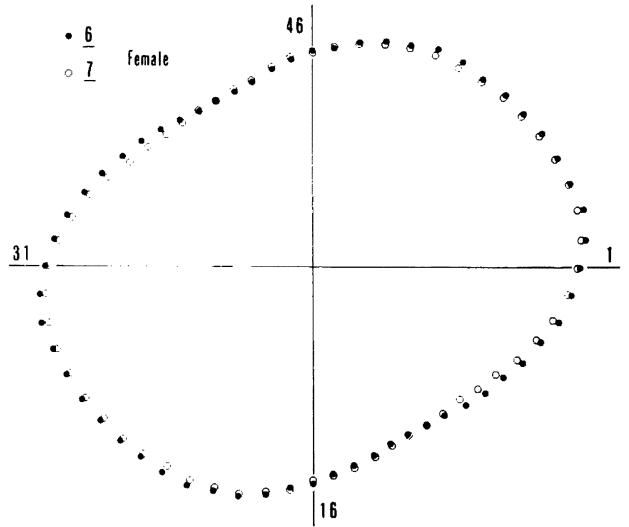

Fig. 9 Curvilinear contours of the first and the second molars in female (Diameter) 
示す部分もあるが，大勢は第 1 大臼歯の歯䅡線輪 郭曲線が第 2 大臼歯より見かけ上大である 傾向を 示していた。また，男子の近遠心方向の第 1 と第 2 大臼歯間には，僅かに 6 と 36,7 と 37 おび 8 と38の 3 つの計測点間に限って有意差が 認められ たが，他の計測点および女子のすべての 計測点に は有意差は認められなかった。

4) 歯䅡線輪郭曲線の直径での性差

男女間の比較については, 第 1 大臼歯は Fig. 10, 第 2 大臼歯は Fig. 11 に各々示した。

直径から得られた歯䅡線輪郭曲線の男女の 比較 では，第 1 ，第 2 大臼歯のいずれの計測点とも， 一部を除く大部分の計測点で男子が女子を上回る 傾向にあった。第 1 大臼歯では第 2 象限と第 4 象 限，すなわち，近遠心方向に相当する部位の 1 か ら14までの計測点と相対する計測点間での 直径に は, Fig. 6 の第 2 象限の遠心相当部に認められた 性差に基うくくと推測される有意差が認められた (Fig. 10)。

第 2 大臼歯では，1，4，6，7，11，29および 30 の各計測点と相対する計測点との間の直径で 有意 な性差が認められた (Fig. 11)。

Fig. 11 の第 2 大臼歯の直径から描かれた歯頝 線輪郭曲線を, Fig. 7 の歯頝線輪郭曲線と比較す ると， 6,7 および11の計測点を除いて直径での結 果とは必ずしも有意差の存在する部位が 対応して いなかった。直径でみる限り第 2 大臼歯の歯䅡線 輪郭曲線の大きさは，全体として第 1 大臼歯と比 較して男女間に有意差を示す部位は少なかった が，Fig. 7 の舌側に見られた男女間の差の影響 が，29と30の計測点に認められた。これらのこと から，第 2 大臼歯は第 1 大臼歯より男女間の輪郭 の大きさの差が小さく，僅かに男子が女子ょり見 かけ上大きい傾向を示すにすぎないことが知れ た。

5) 歯頚線側面観展開図

Table 1〜4 の $\mathrm{Pa}$ の咬頭頂を基準として, こ こから歯䅡線までの高さ（Z）の計測平均值に基 ゔて描いた歯颈線の側面観展開図で，第 1 と第 2 大臼歯間の計測点の位置を比較した男子および 女子の結果を Fig. 12 に示した。

これらの側面観展開図での 4 つの区分は，左か

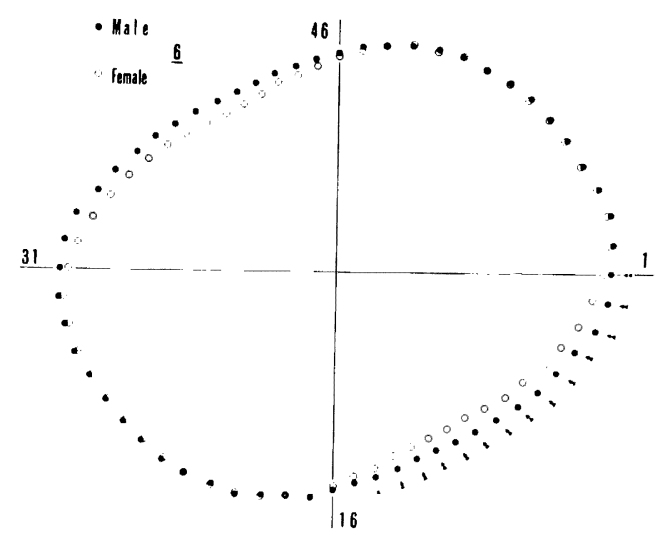

Fig. 10 Curvilinear contours of male and female in the first molars (Diameter)

$\rightarrow: \mathrm{P}<0.05, \longrightarrow: \mathrm{P}<0.01$.

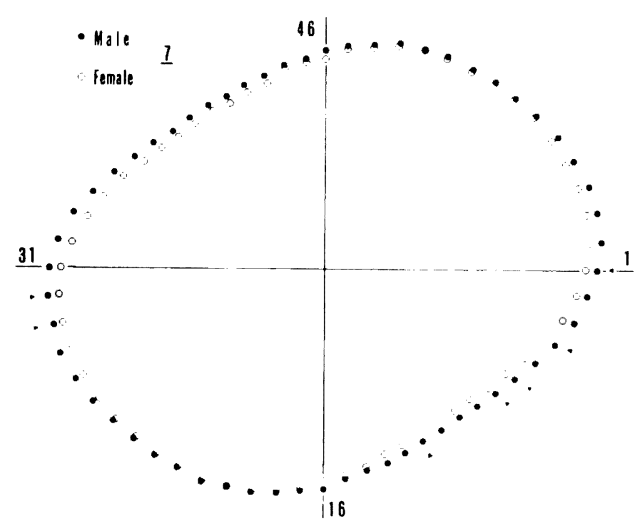

Fig. 11 Curvilinear contours of male and female in the second molars (Diameter)

$\Delta: \mathrm{P}<0.05$

ら歯頝線輪郭曲線での第 4 象限から第 3 , 第 2 , 第 1 象限に各々相当している。

表および図から明らかなように，男子の第1大 曰歯と第 2 大臼歯の比較では, 各々の象限の領域 の計測点のいくつかに差が見られる籄所がある が，いずれの計測点間にも有意差が認められなか った。しかし, 計測点の位置の高低によって描か れる波形からは, 第 2 大臼歯が第 1 大臼歯より幾 分直線的でかつ下位に位置する傾向にあった。た だし，第 3 と第 2 象限では，逆に第 1 大臼歯より 上位に位置する部分も見られた (Fig. 12，上段)。 女子では第 1 象限の煩側相当部を除いて男子と 同様，第 1 大臼歯が第 2 大臼歯より直線的である 

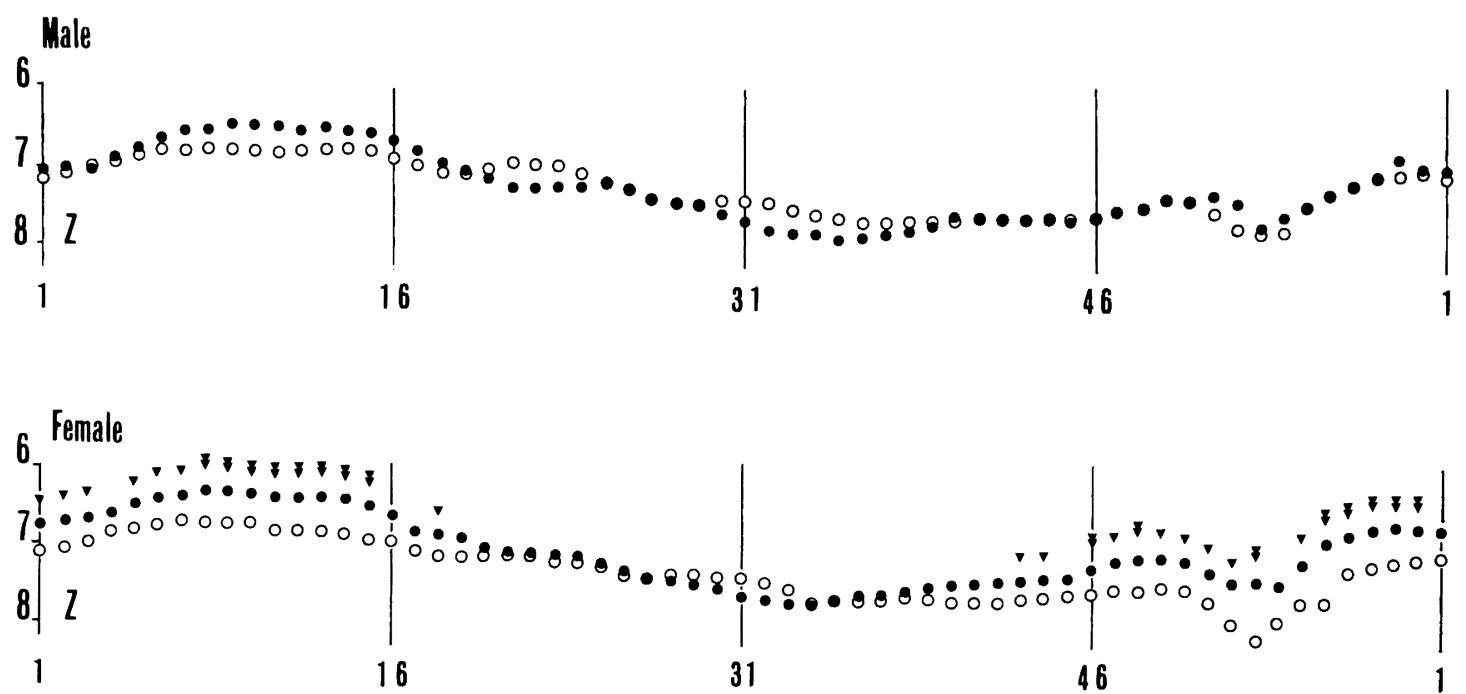

Fig. 12 Lateral aspect of the cervical line

- : First molar, O : Second molar

$\rightarrow: \mathrm{P}<0.05, \longrightarrow: \mathrm{P}<0.01$
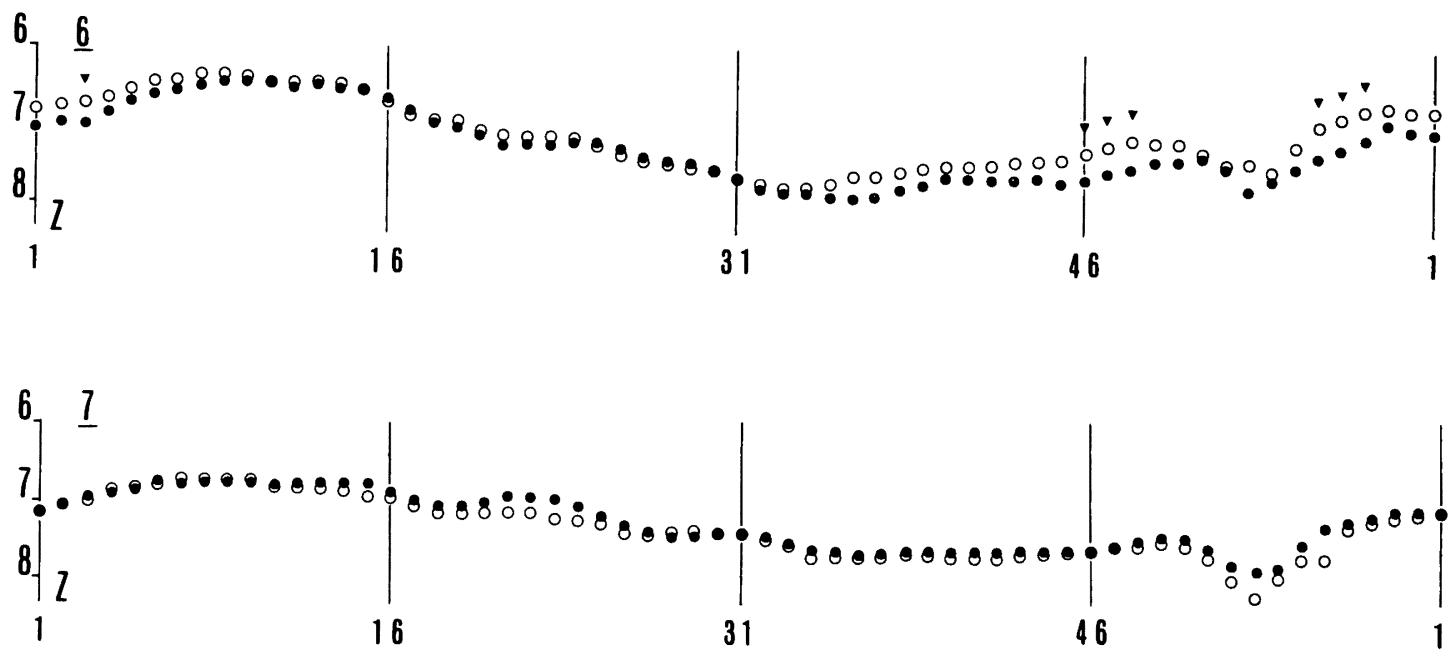

Fig. 13 Lateral aspect of the cervical line

- : Male, $\mathrm{O}$ : Female $\longrightarrow: \mathrm{P}<0.05$

傾向が見られ，第 4 象限すなわち，近心相当部之 第 1 象限の煩側相当部で第 1 と第 2 大臼歯間に有 意差が認められた（Fig. 12，下段)。また，第 3 と第 2 象限の境界相当部には第 1 大臼歯が 第 2 大 臼歯より下位に位置し，他とは逆の現象が認めら れる部位が存在していたが，大勢は第 2 大臼歯が 第 1 大臼歯より下位に位置する 傾向にあった。し たがって，女子の第 1 と第 2 大臼歯間の波形の高
低差は，男子より大である傾向を示すことが知れ た。

6）歯頚線側面観展開図での性差

歯䅡線の側面観展開図での男女間の計測点の位 置を比較した結果を Fig. 13 に示した。

第 1 大臼歯では，歯䅡線の波形の高低差の男女 間の相違は，第 4 象限と第 1 象限の一部に有意な 性差が認められる以外，大部分の計測点で男女間 
の差は少ない傾向にあった。僅かに認められた有 意差の存在する部位も, 多くは第 1 象限すなわち, 煩側に相当する部位にあり，一部第 4 象限すなわ ち, 近心相当部の煩側寄りに偏っていることが知 れた (Fig. 13, 上段)。

第 2 大臼歯では，第 4 から第 1 象限にかけて男 女間の計測点の位置はほぼ一致し，僅かに第 1 象 限の煩側の根分岐相当部で男女間に差のある 傾向 が見られたが，いずれも有意差は認められなかっ た (Fig. 13，下段)。したがって，第 2 大臼歯での 計測点の上下方向の位置は, 男女ともほぼ同様の 傾向を示すと言える。この結果から，女子では男 子と比較して第 1 大臼歯の歯䅡線の波形は，第 2 大臼歯より上下方向への変動が大きいとみなされ た。

\section{考察}

歯䅡線の形状についての観察あるいは計測は， 上部に存在する歯冠部の外側への突出の影響によ って，その位置を正確に捕えることが困難である ことから，これまでにそれらの障害を解決するた めの様々な工夫がこらされてきた ${ }^{1-6)}$ 。しかし, 従 来から用いられてきたいずれの計測方法も，歯䅡 線の形状についての詳細な観察に対して十分に適 合しているとは言い難い。

上顎の第 1 および第 2 大臼歯における各咬頭の いわゆる冠長に相当する長さの計測を行うべく, 三次元測定機を応用して歯䅡線上の計測点を計測 した結果 ${ }^{10)}$ ，起伏が激しくかつ陥入部を有する材 料での計測に極めて有効であったことから，今 回, 従来から計測が困難な部位となっている 歯䅡 線の形状や位置を明らかにするため, 三次元測定 機を導入して計測を実施した。

本観察に用いた三次元測定機に類する機器は, すでに歯科材料の分野で利用され，歯科領域への 応用が可能であることが確認されている(11-13)。そ の後, 歯列における歯の位置に関する観察 ${ }^{14-16)}$ あ るいは本観察で対象とした歯䅡線の観察について も，すでに下䪽第 2 乳臼歯を材料とした計測に応 用され ${ }^{17)}$ ，歯の形態に関する領域へと応用範囲が 広がってきた。

上顎大臼歯の形態については，主として歯冠部
での観察が行われ，列端退化の方向に従って第 3 大曰歯から第 1 大臼歯へと，遠位に存在する歯ほ ど退化の影響が現れ，その量的推移として遠心舌 側咬頭の大きさの減少あるいは消失 ${ }^{18)}$ と近遠心径 の 顕著な 縮小 ${ }^{18,19)}$ についての 歯冠形態の 退化様 式の方向性について極めて明確に図解されてい $3^{181}$ 。一方, 同じ歯冠部で退化示数を導入しての 観察では20)，上顎第 2 大臼歯の冠長および冠厚は, 第 1 大臼歯に対して退化の影響による 縮小よりは むしろ拡大傾向にあることが示され，歯の退化傾 向および退化様式は歯種あるいは部位により特 有で，すべての計測項目で等しく縮小するもので はないことが知れる。

歯䅡線についても前記のごとく，煩側および舌 側での咬頭頂および歯䅡線の近遠心的な 高低差に よる傾斜の状況によっておよその動静が 知れるに すぎない10)。このような状況から今回, 上鿓の第 1 および第 2 大臼歯の歯䅡線の計測を実施して, その形態を三次元的に捕えることを試みたが，歯 頝線の計測平均值（Table 1 4）に基ゔいて描い た歯頚線輪郭曲線の形態からは, 大臼歯での各々 の咬頭の退化の様相を捕えることはできない。し かし，歯䅡線輪郭曲線および歯䅡線側面観展開図 での第 1 と第 2 臼歯との間の相違点を探ることに よって，歯冠部での第 1 と第 2 大臼歯間での変化 の状況を推測することは可能である。

1）第 1 と第 2 大臼歯間の歯頝線輪郭曲線につ いて

歯頝線輪郭曲線の第 1 と第 2 大臼歯間の 比較で は(Fig. 4，5)，男女いずれも第 1 大臼歯と第 2 大 臼歯の歯䅡線の位置の煩舌的な方向での相違は明 らかでない。これに対して歯頝線輪郭曲線の近心 側への偏位が見られ，歯冠部での煩舌径に対し近 遠心径の差が大である18-20)ことと一致している。 これが第 1 大臼歯から第 2 大臼歯への歯䅡線の変 化の動静を示しているように見受けられる。しか し, 各々の計測点の直径について比較した場合, 男子の近遠心径すなわち, 冠幅に相当する方向で

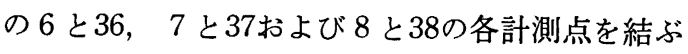
計測点間で，第 1 大曰歯が第 2 大臼歯より有意に 大である差が認められるが (Fig. 8), 他の計測点 および女子の歯頝線輪郭曲線では，いずれの計測 
点間にも第 1 大臼歯が第 2 大臼歯より見かけ上大 である傾向を示すにすぎないことが知れる。

上䇗大臼歯の歯頝線輪郭曲線についての詳細な データがないため, その形状について比較するこ とはできない。しかし，本観察の歯䅡線輪郭曲線 の形態では，第 1 と第 2 大臼歯間に僅かに近遠心 方向で縮小傾向を見ることができるが，一部を除 いて有意な差が認められなかったことで，退化の 影響による歯冠部での変化は, 歯冠の最大膨隆部 において認められる現象で，歯冠との境界部の狭 窄部に存在する歯頝線では, 退化の影響による形 態の相違は現れにくいと考えられる。

歯頝線輪郭曲線の退化の影響による変化の傾向 は，歯頝線輪郭曲線への影響とは別に，計測の原 点である $\mathrm{fmb}$ の位置の変動によっても同様の結 果が得られることが予測される。しかし，今回の 観察では $\mathrm{fmb}$ の位置の移動について明らかにす ることはでき得ないが, 結果として歯頝線輪郭曲 線は，男子の一部を除いて第 1 大臼歯と第 2 大臼 歯間での量的相違による変化は極めて少なく，位 置的な変動が主体であると同時に，近遠心的方向 に限られることが知れる。したがって，歯䅡線の 大勢は単にその位置的偏位にすぎず，退化の影響 による大きさの変化は及んでいないと推察され る。

2）歯頝線輪郭曲線の性差について

歯冠部での咬合面示数を導入した 観察では ${ }^{21)}$, 第 1 大臼歯は女子が有意に大である性差の 存在が 示され，他の大臼歯も女子が男子より大である傾 向にあることが示されていた。しかし，これは固 有咬合面と咬合面観輪郭との相互関係によって成 り立つものであり，歯䅡線輪郭曲線での性差の比 較の対象にはなりにくい。本観察での歯頚線輪郭 曲線の性差は, 第 1 , 第 2 大臼歯ともに男子が女子 より大である傾向を示し，第 3 大臼歯の萌出率 ${ }^{22}$ や側切歯の存在率 ${ }^{23}$ および咬合面観輪郭と 固有咬 合面輪郭での所見 ${ }^{24)}$ と類似していた。また,第 1 大 臼歯は遠心相当部に第 2 大臼歯は逆に近心相当部 に性差が認められ，第 1 と第 2 大臼歯とで性差の 存在する方向に相違がみられるが(Fig. 6，7), 男 子での遠心相当部の 第 1 大臼歯と第 2 大臼歯の計 測点の位置の近心方向への偏位が，女子と比較し
て大きいための結果であることが推察される(Fig. 4，5)。したがって，性差は単に計測点の移動によ る位置的相違に基づくもので，一部を除いて大き さに関する変化はないものとみなされる。歯の大 きさの測度では，冠幅での性差が最も少ない251の に対して，歯頚線での冠厚と冠幅に相当する部で はむしろ冠厚に相当する煩舌径での性 差が 少な く，歯冠部の最大膨隆部を対象とした 結果と異な っていることが知れる。

3）歯䅡線側面観展開図での第 1 と第 2 大目歯 の位置について

$\mathrm{Pa}$ の咬頭頂を基準とした各々の計測点での歯 頝線の高さの状態を示す歯䅡線側面観展開図で, 女子の第 1 大臼歯と第 2 大臼歯との高低差が 男子 と比較して大であったことは，女子での退化の影 響が男子より大きい結果とも考えられる。しかし， 高低差の 存在する 部位が 第 1 と第 2 象限すなわ ち，退化の影響が少ないと見られる部分である近 心および煩側相当部に偏る傾向にあることから， 男女ともに第 1 大臼歯に対して，第 2 大臼歯の冠 長に相当する基準点とした計測点 1 での $\mathrm{Pa}$ の長 さが長いことによる歯頚線の上下方向の位置の変 動の影響に基づく相違とも考えられる。第 2 大臼 歯の歯䅡線の基準点 1 の位置が第 1 大臼歯より下 位に存在することから，高さおよび煩側の根分岐 部での相違を除けば，第 1 大臼歯に対する第 2 大 臼歯の歯頝線の高さの位置的相違を見ることがで きる。この結果は, 退化による影響から考えれば, むしろ第 2 大臼歯での冠長の増大に基づくもので あることから，退化の方向性とは逆行する傾向に あるといえ，退化との関連については更に検討を 要しょう。

計測の基準点である $\mathrm{Pa}$ の位置を, 第 1 と第 2 大臼歯で同一の高さに調整することによって，歯 頝線の側面観展開図の形状は，近心と煩側の領域 で第 1 と第 2 大臼歯とが極めて類似の形態を示す ことが分かる。この結果ではむしろ舌側および遠 心相当部での差が大であることとなる。したがっ て，歯䅡線の形態は，第 2 大臼歯では男女ともに 第 1 大臼歯より直線的であり，第 1 と第 2 大田歯 間での歯䅡線の位置は第 2 大臼歯が 第 1 大臼歯よ り低位すなわち，根尖側にあって両大臼歯間の差 
はむしろ遠心と舌側相当部で大きい。

4）歯颈線側面観展開図の性差について

歯䅡線側面観展開図で第 1 大臼歯の 計測点の 7 点に有意な性差が認められたが，これを先の歯別 差の検討の際に比較したと同様，基準点の計測点 1 の位置を男女同一レベルの高さへ移動して 比較 した場合，ほとんど類似の形態を示すことから， 歯頚線の側面観展開図での性差は, 冠長の高さと の関係による見かけ上の相違とみなされた。すな わち, 男子での $\mathrm{Pa}$ の長さが女子より長いための 高さの差であり，その位置も近心および煩側で差 が大である傾向が見られることから，退化との関 連は考えにくい。しかし，第 2 大臼歯では男女間 でほとんど差がないことは，冠長が第 2 大臼歯で 長いことを除いて波形が緩やか, 寸なわち, 直線的 になる傾向が男女ともに見られることでは単純化 の影響を受けていることが推測される。したがっ て，歯頚線ではその高さの関係と一般的に見られ る歯の退化傾向との関連は明らかでなく，退化傾 向の性差あるいはその様相について 結論づけるに は時期尚早で，さらに今後様々な方向からの探究 の積み重ねが必要であることを示唆している。

\section{結論}

従来から歯の各部の計測に用いられていた方法 では，細部の観察が困難である歯䅡線について， 三次元測定機を導入して計測を行い，下記に示し たような結果が得られた。

1）歯䅡線輪郭曲線は長円形を示し，比較的各 々の方向を示す面との境界が明らかであった。
2）第 1 と第 2 大臼歯との比較では，男女とも に第 2 大臼歯の歯頝線輪郭曲線の位置は, 第 1 大 臼歯より近心方向一偏位する傾向が見られ，男女 によってその位置に相違が見られるが，概して近 遠心方向に有意な差が認められた。

3）直径に換算しての比較で，第 1 と第 2 大臼 歯間には男子の近遠心方向の 3 力所に 有意差が認 められる以外, 有意な差を示す部位は存在せず, 歯頝線での第 2 大臼歯間の相違は，量的なものよ り位置的なむのであることが知れた。

4）歯頚線側面観展開図での第 1 と第 2 大臼歯 間での高低差は，女子の近心および煩側相当部で 第 2 大臼歯が第 1 大臼歯より低い位置にあり，有 意差も認められた。

5）第 1 と第 2 大臼歯各々の男女間には，第 1 大臼歯の煩側相当部に男子より有意に高い位置を 占める性差が認められた。

6）これらの差は冠長による歯頝線の高さの影 響による相違で，第 1 と第 2 大臼歯の $\mathrm{Pa}$ の高さ を一定にすることにより煩側および近心での 形態 は類似し，その結果，遠心と舌側での差が大とな る傾向を示し，歯頝線の高さについては退化の影 響はないとみなされた。

以上の結果，三次元測定機を用いての歯頝線の 計測から，歯䅡線の三次元的な位置関係の詳細が 明らかとなり，その形態と第 1 ，第 2 大臼歯間お よび男女間での 相違点の 傾向を知ることができ た。

抄録：上顎大臼歯歯䅡線の観察に三次元測定機を応用して計測を行った結果，歯頝線の形態，位置につい ての詳細な計測值が得られた。

その結果, 第 2 大臼歯の歯頝線輪郭曲線は, 男女ともに第 1 大臼歯とで近遠心方向に差がみられた。しか し, 各計測点の直径で比較した場合, 第 1 大臼歯が概して第 2 大臼歯より大きい傾向を示すが，ほとんどの計 測点に有意差が認められなかったことで，第 2 大臼歯は第 1 大臼歯より近心に偏位し， 量的な変動は明らか でないことが知れた。

性差は第 1 ，第 2 大臼歯とも男子が女子より大である傾向にあり，第 2 大臼歯では第 1 大臼歯より差が小 さい。

歯顙線側面観の形態は，第 1 と第 2 大臼歯間および性差ともに近心煩側咬頭におけるいわゆる冠長が第 1 より第 2 大臼歯で長く，男子が女子より長いための影響による差の存在が認められるものがあった。

\section{文献}

1）植田昭夫 : 正中矢状平面を 基準にして画かれ た，等高線図法による日本人永久歯の形態学的
研究, その 1 切歯, 犬歯. 歯科学報 66 ? 409-425, 1966.

2）植田昭夫：正中矢状平面を基準にして画かれ た，等高線図法による日本人永久歯の形態学的 
研究, その 2 小臼歯. 歯科学報 66 : 522535, 1966.

3）植田昭夫 : 正中矢状平面を 基準にして画かれ た，等高線図法による日本人永久歯の形態学的 研究, その 3 大臼歯. 歯科学報 66 : 588606, 1966.

4）栗原洋一, 森 貞子, 長谷川徹雄, 兼坂博之 : 乳歯歯頸線の形状観察のための一手法. 日大歯 学 44:656-657, 1970.

5）伊藤武志：歯冠側面の 形態学的研究, (上䫑第 2 小臼歯). 愛院大歯誌 $9:$ 141-169, 1972.

6) 斉藤 一：下顎臼歯部の 歯冠側面形態につい て. 愛院大歯誌 $12: 261-291 ， 1974$.

7）音田清人：日本人下頷永久歯歯頸線の形態学的 研究. 歯科学報 77:661-698, 1977.

8）藤田恒太郎・中山愛一：歯頸部に於ける珐瑯 質境界線の 形態学的研究. 口腔病学会誌 14 : 355-363, 1940.

9）藤田恒太郎：歯の計測基準について．人類誌 61:27-32, 1949.

10）久保田公雄，松沢小百合，村松一：上萼页大臼 歯の咬頭頂の位置および咬頭頂と歯頚部の傾斜 パターン. 日大歯学, 投稿中, 1991.

11）岩尾 徽 : 三次元測定機による中型間接模型の 膨張精度に関する研究 [I] 三次元測定機の有 用性の検討. 日歯材料器械会誌 34: 136-147, 1977.

12）土生博義, 平口久子, 小林孝誌, 田辺直紀, 茂 木孝之: 三次元座標測定システムの歯科材料へ の応用 (第 1 報) 装置の概要と測定精度. 日大 歯学 56 : 914-920, 1982

13）稲葉 繁，是沢恵三，萩原重一，鐘ヶ江修，川 名孝義, 亀沢籁之：三次元座標測定機の歯学研 究への応用. 日補緅誌 $25: 55-60,1981$.

14）川名孝義：上下顎歯牙の Overlap 量と側方位
歯牙接触様式について一三次元座標測定機によ る研究一. 歯学 68 : 763-787, 1981.

15）亀沢筑之：上下颚臼歯における咬頭頂と咬合面 窝の対向関係について一三次元座標測定機によ 万研究一。歯学 $68: 788-805,1981$.

16）川嶋三郎：前頭面における上下顎犬歯尖頭およ び臼歯各咬頭頂の位置関係について一三次元座 標測定機による研究一. 歯学 $70: 1230-1246$, 1983.

17）小金井庄兵衛 : 乳歯歯䅡線の形態学的研究一下 頷第二乳臼歯の三次元的形状観察一. 日大口腔 科学 16 : 145-153, 1990 .

18）藤田恒太郎, 桐野忠大 : 歯の解剖学, 第19版, 70 , 金原出版, 東京, 1974.

19) Ozaki, T., Satake, T. and Kanazawa, E. : Morphological Significance of Root Length Veriability in Comparison with Other Dimensions I . Basic Statistics and Sex Difference, J. Nihon Univ. Sch. Dent. 29 : 233240, 1987.

20）尾㠃 公: 日本人の歯の退化示数. 解剖誌 35 : 563-577, 1960.

21）糟谷勝一：日本人大臼歯の咬合面示数につい て. 日大歯学 43: 135-139, 1969.

22）河西秀智：日本人における智歯の統計的観察 （智歯の出現, 発育, 萌出の時期と頻度につ、 て). 口腔病会誌 $26: 463-480,1959$.

23）住谷 靖：日本人における歯の異常の統計的観 察. 人類誌 $67: 215-233,1959$.

24）沓澤栄一：日本人の歯冠の平均形態に関する解 析的研究 第 3 報, 上鿓第 2 大臼歯の咬合面観 輪郭の形態について. 日大口腔科学 $5: 22-31$, 1979.

25）権田和良：歯の大きさの性差について．人類誌 67 : 151-163, 1959 